\title{
LA FUNCIÓN DE LA LEALTAD EN EL ESTADO AUTONÓMICO
}

\author{
LEONARDO ÁLVAREZ ÁLVAREZ \\ Profesor de Derecho Constitucional \\ Universidad de Oviedo
}
SUMARIO
I. El concepto de lealtad constitucional. La función de la norma de lealtad al princi- pio autonómico en la CE
II. La norma de lealtad autonómica como exigencia teórico-funcional del principio autonómico
III. La plasmación jurídico-normativa de la lealtad autonómica. La concepción dog- mática de la lealtad autonómica en la $\mathrm{CE}$

La existencia de ordenamientos jurídicos territorialmente descentralizados- como el que se reconoce en la CE de 1978-, además de presentarse en la actualidad como una exigencia del principio democrático, se erige en un instituto prácticamente ineludible para poder asegurar eficazmente la regulación del uso de la fuerza, como objeto de la actividad normativa del Estado. ${ }^{1}$ En efecto, al igual que sucede con las funciones de creación y de aplicación de normas — que incluso en los regímenes más autoritarios son objeto de una mínima distribución orgánica- ${ }^{2}$ también aparece como consustancial a todo ordenamiento jurídico, siquiera una básica descentralización territorial de dichas funciones. Sin embargo, la cuestión de la descentralización territorial sigue siendo todavía hoy en día objeto de constantes construcciones tanto a nivel doctrinal como jurisprudencial, cuya finalidad ha sido fundamentalmente

1 Véase Kelsen, H., Reine Rechtslehre, ed. Franz Deuticke, Viena, 1976, pág. 34 y ss.

2 Cfr. Kelsen, H., Allgemeine Staatslehre, ed. Max Gehlen, Berlín, 1966, pág. 334 y ss. 
atenuar los efectos de las fuerzas centrífugas que, derivadas del instituto mismo de la descentralización, puedan poner en peligro el funcionamiento eficaz del Estado como unidad normativa, en la que se integran las diferentes entidades descentralizadas. ${ }^{3}$ Esta exigencia dogmática de unidad — que, si bien con otros parámetros, cabe identificar tanto en la teoría general del derecho como en la doctrina tradicional del Estado -4 cobra una mayor intensidad en el seno de un ordenamiento democrático — como el español (art. 1,1 CE) — que reconoce a las entidades descentralizadas, concretamente, el ejercicio de la potestad legislativa (autonomía política), adquiriendo sus normas el mismo rango que las dictadas por el Estado Central. ${ }^{5}$

Este modelo de Estado, que ha sido asumido por la $\mathrm{CE}$, y que puede ser calificado formalmente de diversos modos-cantonal, regional o autonómi$\mathrm{CO}-$, e incluso estructurado internamente con arreglo a criterios definidamente propios - como puede ser la existencia o no de una Constitución aprobada por las entidades descentralizadas-, responde materialmente a grandes rasgos al modelo del Estado federal. Ha sido precisamente en el marco de la teoría del Estado Federal donde se ha planteado de manera más intensa la exigencia de que las funciones constitucionales de creación y de aplicación de normas, descentralizadas territorialmente, bien se ejerzan para el desarrollo de la unidad del Estado de la que forman parte, bien, al menos, de manera no lesiva para la misma. ${ }^{6}$ Esta exigencia dogmática es la que permite explicar la plasmación en las Constituciones de normas tales como la prevalencia, la supletoriedad o la coerción federal, cuya función normativa es precisamente garantizar el funcionamiento eficaz del Estado federal unitario. ${ }^{7}$

Sin embargo, resulta curioso apreciar cómo en la práctica totalidad de los casos las normas constitucionales que reconocen una pluralidad territorial de fuentes de producción normativa han requerido de una cierta corrección a través de una norma de naturaleza hermenéutica - funcionalmente concebida como una cláusula de cierre del sistema - destinada a reforzar la unidad y, en último extremo, la realización del ordenamiento descentralizado. Esa norma

3 Cfr. STEIn, E., Staatsrecht, ed. JCB Mohr, Siebeck, 1990, pág. 320.

4 Véase al respecto en la teoría general del derecho sobre el principio de unidad del orden jurídico, Larenz, K., Methodenlehre der Rechtswissenschaft, ed. Springer, Berlín, 1979, pág. 133 y ss. En el ámbito de la teoría general del Estado, en concreto, en la teoría clásica de la corporación, véase JelunneK, G., Allgemeine Staatslehre, ed. Julius Springer, Berlín, 1929, pág. 146 y ss. También en ese sentido Kelsen, H., "Der Staat als Integration" en idem., Drei Kleine Schriften, ed. Scientia, Aalen, 1994, pág. 9.

5 En el caso del principio autonómico, véase la STC 25/1981, FJ. 3o.

6 Véase Hesse, K., Der unitarische Bundesstaat, ed. CF. Müller, Heidelberg 1962, pág. 9 y ss., SMEND, R., "Ungeschriebenes Verfassungsrecht im Monarchischen Bundesstaat", en idem., Staatsrechtlichen Abhandlungen, ed. Duncker \& Humblot, Berlín, 1968, pág. 12; TriePel, E., Unitarismus und Föderalismus im Deutschen Reiche, ed. JCB Mohr, Tubinga, 1907, pág. 29 y ss y ScheunER, U., "Struktur und Aufgabe des Bundesstaates in der Gegenwart", Die Öffentliche Verwaltung, núm. 17/18, 1962, pág. 646.

7 Cfr. Bullinger, M., "Zum Verhälnis von Bundesaufsicht und Bundestreue", Archiv des Öffentlichen Rechts, núm. 87, 1962; AnschüTZ, G., "Das Reichsaufsicht" en AnschüTz, G. у ThOмA, R., Handbuch des Staatsrechts, tomo I, ed. JCB Mohr, Tubinga, 1930, pág. 368. 
que, como tal, paradójicamente no ha encontrado plasmación expresa en los documentos constitucionales es la que se conoce en la ciencia del Derecho Constitucional como lealtad federal. ${ }^{8}$ Esta exigencia de reforzamiento de la unidad del Estado descentralizado que expresa la lealtad federal, y de la que traen su causa otras categorías idénticamente hermenéuticas, ${ }^{9}$ - también asumidas por el Tribunal Constitucional español- ${ }^{10}$ surgen, desde luego, en la CE de 1978, que garantiza en el seno de la misma la autonomía de las nacionalidades y regiones (art 2).

\section{EL CONCEPTO DE LEALTAD CONSTITUCIONAL. LA FUNCIÓN DE LA NORMA DE LEALTAD AL PRINCIPIO AUTONÓMICO EN LA CE}

\section{CONCEPTO Y FUNCIÓN DE LA LEALTAD CONSTITUCIONAL. LA LEALTAD AUTONÓMICA.}

El concepto de lealtad constitucional ha sido empleado por la ciencia del Derecho Constitucional para referirse, con carácter general, a una norma plasmada en ciertos textos constitucionales aprobados con posterioridad a la Segunda Guerra Mundial, que se caracteriza por plantear una particular forma de infracción de las normas constitucionales. Con la expresión lealtad constitucional se alude a una norma o un conjunto de normas constitucionales que desempeñan la función normativa consistente en dotar de eficacia al contenido de uno o de varios principios estructurales. En ese sentido, lo definitorio de la norma de lealtad es su objeto (un principio estructural) y su función normativa (dotarle de eficacia). Sin embargo, y aunque con carácter general haya sido relativamente pacífico ubicar la génesis de la lealtad constitucional

8 Véase en el caso del ordenamiento alemán IsEnsee, J., "Idee und Gestalt des Föderalismus im Grundgesetz" en Iseensee, J. y KirchHof, P. (edits.), Handbuch des Staatsrechts, tomo IV-Finanzverfassung. Bundesstaatliche Ordnung-, ed. CF. Müller, Heldelberg, 1990, pág. 532. En el ordenamiento austriaco Pernthaler, P., Allgemeine Staatslehre, ed. Springer, Viena-Nueva-York, 1986, pág. 431. Para el caso del ordenamiento belga, véase Alen A. y OTros, "Bundestreue im belgischen Verfassungsrecht", Jahrbuch des Öffentlichen Rechts, núm. 42, 1995, pág. 492 y ss. Para Italia, Anzon, A., La Bundestreue e il sistema federale tedesco: un modello per la riforma del regionalismo en Italia, ed. Giuffrè, Milán, 1995, pág. 75 y Bartole, S., Bin, R., Falcon, G. y Tosi, R., Diritto regionale. Dopo la riforme, ed. Il Mulino, Bolonia, 2003, pág. 203. En el caso suizo Kolz, A., "Bundestreue als Verfassungsprinzip?", Schweizerisches Zentralblatt für Staats-und Gemeindeverwaltung, núm. 81, 1980, pág. 148 y ss.

9 Como ha sucedido, por ejemplo, con las categorías jurisprudenciales de la "Natur de Sache" o la competencia "Kraftsachzusammenhang", que han sido utilizadas por el Tribunal Constitucional Federal alemán como normas metacompetenciales. Véase ejemplificativamente la BVerfGE 106, 62. Un análisis de las mismas desde la perspectiva de la realización de la eficacia del principio federal puede verse en BADura, P., "Verfassungsänderung, Verfassungswandel, Verfassungsgewohnheitsrecht" en IsEnSEE, J. y KIRCHHOF, P. (edits.), Handbuch des Staatsrechts, vol. VII —Normativität und Schutz der Verfassung_, ed. CF. Müller, Heidelberg, 1992, pág. 57 y ss. 10 Véanse respectivamente las SSTC 61/1997, FJ $8^{\circ}$ y 209/1990, FJ $4^{\circ}$. 
en el periodo posterior a la Segunda Guerra Mundial —en clara respuesta a los episodios de radicalismo político protagonizados por el partido nacionalsocialista durante la vigencia de la Constitución de Weimar de 1919_, , ${ }^{11}$ lo cierto es que la categoría de la lealtad constitucional encuentra, en sentido estricto, su acta fundacional en los albores mismos del Estado federal, incluso cuando ni siquiera los Estados llegaron a asumir propiamente tal forma. ${ }^{12}$ Puede afirmarse efectivamente que, de manera contraria a lo que ha sido usual en la doctrina, que ha venido a identificar la lealtad con los modernos institutos destinados a responder frente a los enemigos de la Constitución, ${ }^{13}$ el concepto de la lealtad constitucional tiene su origen históricamente en la teoría y en la práctica del Estado federal.

En este contexto, instituto de la lealtad (federal) aparece como una norma-no siempre jurídica-que desempeña la función de garantizar el funcionamiento eficaz del Estado descentralizado, si bien los diferentes contenidos normativos a través de los que pretendió desempeñarse su función fueron bien diversos, como se analizará más adelante. ${ }^{14}$ Sólo durante la última mitad del siglo XIX, con la difusión de la doctrina del positivismo jurídico —y más tarde, ya entrado el siglo xx, con la teoría del positivismo-normativista- el concepto de lealtad (federal) pudo ya ser objeto de un tratamiento propiamente jurídico, ${ }^{15}$ aunque fuera en la mayor parte de las ocasiones para negar su concepción como una categoría autónoma en el seno de lo que pudo denominarse ya verdaderamente una ciencia del Derecho Constitucional, al achacar a la lealtad la adopción de un contenido coincidente con la categoría

11 En particular, en respuesta a la propia supresión de la democracia consagrada en el texto constitucional de 1919 a través de los propios procedimientos democráticos. Eso es lo que permite explicar que el concepto de lealtad constitucional haya aparecido en las Constituciones actuales como una norma que pretende responder frente a las conductas que, aun por los procedimientos democráticos, pongan o puedan poner en peligro la eficacia del principio democrático fundamentalmente, pero también de los demás principios estructurales de la Constitución. Véase Becker, J., "Die wehrhafte Demokratie des Grundgesetzes" en IsEnSEe, J. y KirchHOF, P. (edits.), Handbuch des Staatsrechts, vol. VII — Normativität und Schutz der Verfassung-, op. cit., pág. 316 y 317 y STERN, K., Zur Verfassungstreue der Beamten. Studien zum öffentlichen Recht und zur Verwaltungslehre, núm. 12, Múnich, 1974, pág. 12.

12 Sobre su surgimiento en el siglo XVI, parcialmente coincidente con el nacimiento de la moderna teoría del Estado, cfr. BAuER, H., Die Bundestreue, ed. JCB Mohr, Tubinga, 1992, pág. 30 y ss. Un poco más tardíamente, véase SMEND, R., "Ungeschriebenes Verfassungsrecht im Monarchischen Bundesstaat", op. cit., pág. 12. En realidad, a este autor se le debe la primera construcción teórica sobre la lealtad federal en el contexto de la Constitución del alemana de 1871.

13 Véase al respecto Röllecke, G., "Verfassungstreue und Schutz der Verfassung" en idem., Augeklärter Positivismus. Ausgewählten Schriften zu den Voraussetzungen des Verfassungsstaates", ed. CF. Müller, Heidelberg, 1995, pág. 171, así como Denninger, E., «Verfassungstreue und Schutz der Verfassung", Veröffentlichungen der Vereinigung der Deutschen Staatsrechtslehrer, núm. 37, 1979, pág. 17.

14 En la doctrina española puede verse un detallado análisis de este aspecto en ALBERTí RoVIRA, E., Federalismo y cooperación en la República Federal Alemana, ed. Centro de Estudios Constitucionales, Madrid, 1986, pág. 235 y ss.

15 Cfr. Laband, P., Das Staatsrecht des Deutschen Reiches, ed. JCB. Mohr, Tubinga, 19111914, pág. 143 y ss. 
de la sujeción al derecho. ${ }^{16}$ Esta posición ha encontrado, en cierta medida, también un acomodo en la teoría constitucional actual, que ha llegado a postular la irrelevancia del concepto de lealtad constitucional aplicado al funcionamiento del Estado federal al constituir una reduplicación de categorías ya existentes que, en el fondo, se vinculan a la categoría de la sujeción ${ }^{17}$. Sin embargo, desde una perspectiva teórico-funcional hay buenos motivos para rechazar que ello pueda ser así.

Como se tuvo la ocasión de poner de relieve con anterioridad, la norma de lealtad, al tener por objeto la eficacia de los principios estructurales, pretende construirse sobre la base de una distinción entre lo que es la infracción de las normas constitucionales que plasman los citados principios y la infracción del resto de las normas de la Constitución. Tal diferenciación cobra una especial relevancia si se tiene en cuenta que el contenido de los principios estructurales aparece materializado comúnmente en diferentes normas constitucionales e incluso infraconstitucionales. Eso es lo que sucede precisamente en la CE, en la que el principio autonómico del art. 2 se concreta en diferentes disposiciones constitucionales, muy particularmente en las que se recogen en el Título VIII. Sin embargo, el hecho de que la norma de lealtad tenga por objeto el contenido nuclear de un principio estructural, pone de manifiesto su intención de distinguir, en último extremo, lo que es la infracción genérica de las normas constitucionales - que cabe ser tildada formalmente de sujeción - de aquella otra infracción que, por su particular intensidad, resulta susceptible de poner en peligro la existencia misma del principio estructural que aquellas otras normas concretan o desarrollan —lealtad constitucional-.

En consecuencia, plantearse en el ordenamiento español la posible existencia de una norma de lealtad al principio autonómico del art 2 CE es preguntarse sobre qué tipo de conductas pueden poner en peligro su existencia misma; más allá de aquellas otras actividades que pueden constituir una infracción puntual de las disposiciones en las que se materializa el principio au-

16 Cfr. Kelsen, H., Allgemeine Staatslehre, op. cit., pág. 274 y 275. Sin embargo, tal afirmación se produjo en el contexto del intento de juridificar desde presupuestos de derecho positivo determinados nexos interpersonales (de lealtad) existentes en la doctrina política preestatal, caracterizada por la confusión de diferentes órdenes normativos, como el derecho, la moral o la religión. Conforme a estos elementos, la lealtad se concibió como el nexo moral de unión entre vasallos y seños feudal. Cfr. GIERKE, O. vON, Das deutsche Genossenschaftsrecht, tomo III, ed. Akad. Dr.- u. Verlagsanst, Graz, 1954, pág. 280 y ss. Véase también MerkL, A., "Die Staatsbürgerpflichten nach Katholischer Staatsauffassung" en Klekatsky, H., Marcic, R. y Schambeck, H., Die Wiener Rechtstheoretische Schule, tomo I, ed. Europa, Viena, Francfort, Zúrich, 1968, pág. 482 y s. Eso es lo que permite explicar lógicamente que la lealtad cuando tiene por objeto, en general, el Estado y el ordenamiento jurídico-que pasa ahora a concebirse como persona ficta y objeto de la norma de lealtad - carezca de sentido hablar de lealtad al caer inequívocamente en el ámbito de la sujeción.

17 Como el abuso de derecho o la buena fe; véase al respecto ScheunER, U., "Struktur und Aufgabe des Bundestaates im Gegenwart, Die Öffentiche Verwaltung, 1962, pág. 642 y Fuß, W., Die Bundestreue_-ein unentbehrlicher Rechtsbegriff?, Die Öffentliche Verwaltung, núm. 2, 1964, pág. 40. 
tonómico. ${ }^{18}$ Sin perjuicio de que posteriormente se ahonde sobre la cuestión, el objeto y la función propios de la norma de lealtad resultan compartidos por diferentes disposiciones plasmadas expresamente de la CE, como la solidaridad, los institutos de colaboración y la facultad de coerción autonómica que, en lo que tienen de común, tratan de garantizar el funcionamiento eficaz del Estado autonómico a través de su incidencia en la eficaz realización del modelo transversal de reparto competencial, ${ }^{19}$ que conforma uno de los contenidos nucleares del principio estructural del art. 2 CE. Tales normas han servido, en parte, para construir en el ordenamiento jurídico español lo que se ha dado en llamar un "principio de lealtad autonómica". ${ }^{20}$

\section{LA FUNCIÓN DE LA NORMA DE LEALTAD AL PRINCIPIO AUTONÓMICO EN LA CE}

La función normativa de la lealtad constitucional consistente en dotar de eficacia al contenido de uno o de varios principios estructurales plasmados en la Constitución no sólo circunscribe sus efectos normativos sobre aquel específico objeto. La pretensión de eficacia que expresa la lealtad constitucional se acaba proyectando, en último extremo, sobre la eficacia generalizada del ordenamiento jurídico, que se presenta como una condición teórica indispensable para que aquél pueda ejercer válidamente su función consistente en regular las condiciones del ejercicio de la fuerza. ${ }^{21}$ En efecto, el derecho, si no pretende quedar relegado a una mera construcción ideal carente de toda entidad práctica, sólo puede considerarse válido si es susceptible de provocar a

18 Eso se ha puesto de manifiesto precisamente en la construcción jurisprudencial de la lealtad federal desarrollada por el Tribunal Constitucional alemán, que ha negado que una mera infracción competencial por parte de los miembros del Estado federal pueda constituir al mismo tiempo una vulneración del principio federal, sino tan sólo la que pueda poner en peligro su funcionamiento mismo. Véase la BVerfGE. 14, 197 (215). En efecto, Las competencias atribuidas por la Constitución federal a sus miembros constituyen, en realidad, el desarrollo del contenido nuclear del principio estructural del Estado federal conformado, entre otras normas, por la que establece un reparto de competencias entre el Estado Central y los Estados federados. Pues bien, lo que se ha puesto de manifiesto por el Tribunal Constitucional alemán es efectivamente cómo la infracción de una determinada competencia no afecta a la eficacia misma del reparto competencial como principio general sobre la que se construye el Estado federal.

19 Véase en lo que se refiere a la solidaridad Muñoz Machado, S., Derecho Público de las Comunidades Autónomas, vol. II, ed. Cívitas, Madrid, 1984, pág. 184, 185 y 186. En lo que respecta a los institutos de colaboración, véase AlberTí Rovira, E., "Las relaciones de colaboración entre el Estado y las Comunidades Autónomas", Revista Española de Derecho Constitucional, núm. 14, 1985, pág. 139.

20 Véase al respecto AJA, E., El Estado autonómico. Federalismo y hechos diferenciales, ed. Alianza, Madrid, 1999, pág. 142, y más recientemente Biglino Campos, P., "Lealtad constitucional en el Estado de las Autonomías", Revista Jurídica de Castilla y León, número extraordinario "25 años de Constitución: lo que nos une", 2004, pág. 69.

21 Acerca de esta concepción de la eficacia generalizada del ordenamiento jurídico como una condición fáctica para la presuposición de su validez, véase Kelsen, H., Reine Rechtslehre, op. cit., pág. 219 y Allgemeine Staatslehre, op. cit., pág. 18 y 19. 
grandes rasgos una ordenación real de la conducta humana. ${ }^{22}$ De acuerdo con este presupuesto cabe afirmar que la norma de lealtad constitucional, al ejercer genéricamente la función de tutelar la eficacia de determinadas normas de la Constitución pretende garantizar la eficacia del ordenamiento jurídico y, por lo tanto, su diferenciación frente a otros órdenes sociales. ${ }^{23}$ Sin embargo, dicha función no la desempeña en exclusividad la norma de lealtad constitucional, sino, en general toda norma (de sujeción) que de una u otra manera pretenda responder frente a la infracción de las normas del ordenamiento.

Sin embargo, del mismo modo que las normas que desean garantizar la eficacia de las normas constitucionales inciden de una manera más intensa en la eficacia generalizada del ordenamiento que las que tratan de responder frente a la infracción de las disposiciones infraconstitucionales, ${ }^{24}$ también dentro de la propia Constitución parece oportuna una distinción similar. Si la Constitución se concibe como una norma suprema y, por tanto, como el fundamento de validez de las normas del ordenamiento, en la determinación de su eficacia de conjunto debe tenerse en cuenta precisamente la eficacia de las normas que más extensa e intensamente regulan el modo en la que se lleva a cabo la creación normativa en sus niveles superiores, esto es, los principios estructurales. En consecuencia, cabe afirmar que la norma de lealtad, al pretender garantizar la eficacia precisamente de los principios estructurales, ejerce de la manera más intensa y directa posible la función de garantizar la eficacia generalizada del ordenamiento jurídico como condición de su validez y de su diferenciación frente a los demás órdenes normativos sociales. Por eso, la lealtad constitucional constituye la plasmación más palmaria del principio de eficacia del ordenamiento jurídico, algo que, sin embargo, no sucede en el caso de la norma de sujeción a la Constitución.

En virtud de lo ahora expuesto, analizar la eventual existencia de una norma de lealtad al principio autonómico plasmado en el art. 2 de la CE es examinar, en el fondo, una de las condiciones dispuestas por el ordenamiento español para poder garantizar su propia eficacia y diferenciarse del resto de sistemas sociales. Pero el estudio de la lealtad al principio autonómico adquiere todavía una mayor relevancia si se tiene en cuenta que el principio au-

22 Cfr. Kelsen, H., Reine Rechtslehre, op. cit., pág. 220 y 221. Cuando esto sucede, el derecho puede diferenciarse adecuadamente de otros órdenes sociales, como la política, la moral o la religión, que también desempeñan la función de regular la conducta humana, aunque mediante normas que predeterminan otra clase de sanciones (políticas, morales o divinas). En ese sentido, cabe afirmar que la eficacia generalizada del ordenamiento jurídico se presenta como una condición funcional indispensable de la diferenciación del derecho como sistema social.

23 Y así, por ejemplo, en la Constitución Española, esta es la función que también desempeñan el art. 9,1 en el que se impone el mandato de cumplimiento de las disposiciones del ordenamiento jurídico, o los arts. 161 y ss. que regulan la función garantista de la Constitución por parte del Tribunal Constitucional, véase al respecto Tomás y VALIENTE, F., "La defensa de la Constitución", Revista de Derecho Político, núm. 16, 1983, pág. 188.

24 Cfr. Kelsen, H., "Vom Geltungsgrund des Rechts" en Klekatsky, H., Marcic, R. y SchamBECK, H., (edits.), Die Wiener Rechtstheoretische Schule, tomo II, ed. Europa, Viena, Francfort, Zúrich, 1968, pág. 1422. 
tonómico en la $\mathrm{CE}$ —en el entramado normativo de los principios estructurales reconocidos en los arts. 1,1, 2 y 93 - constituye una materialización especialmente intensa del principio de Estado democrático de derecho, ${ }^{25}$ que establece las condiciones funcionales básicas para que un ordenamiento pueda ser verdaderamente eficaz. ${ }^{26}$ Por eso, el análisis de la lealtad autonómica aborda, indirectamente, buena parte de las condiciones funcionales de la eficacia y de la diferenciación del ordenamiento español en su conjunto. Pues bien, una vez aclarado el concepto de lealtad constitucional y, sobre todo, la función llamada a ser ejercida por ella, y muy particularmente de la norma de lealtad al principio autonómico, corresponde proceder a analizar si en la CE es posible encontrar alguna norma destinada a desempeñar su función normativa, algo que ya ha sido subliminalmente avanzado con anterioridad.

\section{LA NORMA DE LEALTAD AUTONÓMICA COMO EXIGENCIA TEÓRICO-FUNCIONAL DEL PRINCIPIO AUTONÓMICO}

LA LEALTAD COMO EXIGENCIA TEÓRICO-FUNCIONAL DEL PRINCIPIO AUTONÓMICO: LA TEORÍA DE LA CONSUSTANCIALIDAD DE LA LEALTAD AUTONÓMICA

Una de las maneras más extendidas de fundamentar la existencia de una norma de lealtad, en general, a todo principio estructural que descentralice territorialmente la función de creación de normas, ha sido la aplicación de la que puede denominarse "teoría de la consustancialidad". La presente doctrina - subyacente al origen mismo de la construcción de la lealtad federal, y que como se verá, ha sido asumida por buena parte de la doctrina y de la jurisprudencia españolas $-{ }^{27}$ concibe a la lealtad como una norma consustancial, o si se quiere, inherente, al principio estructural que articula una descentralización territorial. La teoría de la consustancialidad ha pretendido justificarse $-\mathrm{y}$ ello al margen de las diversas concepciones metodológicas desde la que la lealtad ha llegado a sostenerse- en lo que podría llegar a caracterizarse, efectivamente, como una exigencia lógico-jurídica o, expresado en otros términos, dogmático-funcional: que ningún ordenamiento descentralizado podría funcionar de una manera plenamente eficaz si las diferentes partes de lo conforman no adoptaran, en el ejercicio de sus funciones propias, una conducta destinada a reforzar, o al menos, a salvaguardar, el funcionamiento unitario del sistema. ${ }^{28}$

25 Véase Portero Molina, M., "Principio democrático y principio de autonomía", Revista de la Facultad de Derecho de la Universidad Complutense, núm. 21, 1997, pág. 185.

26 Cfr. Aláez Corral, B., Los límites materiales a la reforma de la Constitución de 1978, ed. Centro de Estudios Políticos y Constitucionales, Madrid, 2000, pág. 115 y ss.

27 Véase ejemplificativamente en la doctrina con carácter general AJA, E, Tornos, J.,Font, T., Perulles, J. M., Albertí, E., El sistema jurídico de las Comunidades Autónomas, ed. Tecnos, Madrid, 1985, pág. 85 y 86. En la jurisprudencia véase la STC 64/1990, FJ. 7.

28 Cfr. Eнмке, H., "Prinzipien der Verfassungsinterpretation", Veröffentlichungen der Vereinigung der Deutschen Staatsrechtslehrer, núm. 20, 1963, pág. 77 y 78. Esta exigencia lógica se ve 
Esta exigencia teórico-funcional de garantía de la unidad allí donde en el marco de ésta se reconoce una pluralidad de fuentes de producción normativa ha parecido ser asumida en el ordenamiento español. ${ }^{29}$ Así lo ha reconocido el Tribunal Constitucional, al afirmar que la autonomía no se garantiza en la Constitución - como es obvio- para incidir de forma negativa sobre los intereses generales de la Nación, ${ }^{30} \mathrm{o}$ al sostener en su sentencia más señera en esta materia que este deber (de lealtad), que no es menester justificar en preceptos, se encuentra implícito en la propia esencia de la forma territorial del Estado que se implanta en la Constitución. ${ }^{31} \mathrm{Y}$ ciertamente, esta exigencia teórico-funcional quizás pudiera llegar a entenderse reforzada desde un punto de vista jurídiconormativo en el art. $2 \mathrm{CE}$, cuyo enunciado garantiza el principio de autonomía de las nacionalidades y regiones, aunque dentro del principio de unidad. Ha sido precisamente el reconocimiento de aquella diversidad en el seno de una unidad lo que ha servido para afirmar de forma mayoritaria la existencia de lo que se ha denominado un principio de lealtad autonómica. ${ }^{32}$

La construcción ahora expuesta permite, en realidad, apreciar adecuadamente cuál es la naturaleza y la función de la norma de lealtad constitucional en el marco de la teoría de la consustancialidad. La lealtad, como norma teórico-funcional inherente al principio que descentraliza territorialmente la función de creación de normas - y también lógicamente al principio autonómico plasmado en el art. $2 \mathrm{CE}$ - asume la naturaleza de lo que se ha caracterizado en la ciencia del Derecho Constitucional como Derecho Constitucional no escrito —Ungeschriebenes Verfassungsrecht,$-{ }^{33}$ desempeñando la función normativa de incidir externamente sobre el reparto competencial realizado por el texto constitucional. ${ }^{34}$ La lealtad constitucional aparece, pues, como una norma metapositiva (en el sentido más amplio del térmi-

representada en el clásico símil utilizado originariamente por STEIN de que el Estado federal plasmado en la Ley Fundamental de Bonn es un carruaje formado por 12 caballos, y el Estado se disgregaría si cada uno de ellos tomase una distinta dirección; cfr., Staatsrecht, op. cit., pág. 320. Esta exigencia (lógica) ha sido también utilizada por la doctrina para afirmar la existencia igualmente de una norma de lealtad al principio de no concentración de los poderes del Estado, que ha sido denominada como de lealtad interorgánica, cfr. THOmA, R., "Rechtsgutachten betreffend die Stellung des Bundesverfassungsgerichts", Jahrbuch des Öffentichen Rechts, núm. 6, 1956, pág. 206.

29 En la doctrina esta teoría de la consustancialidad ha sido expresada en los mismos términos apuntados por la doctrina clásica del Estado federal, reseñada en la nota anterior, por JiMÉNEZ AsEnsio, R., Las competencias autonómicas de ejecución de la legislación del Estado, ed. Cívitas, Madrid, 1993, pág. 231.

30 STC 4/1981, FJ $10^{\circ}$. Esta doctrina ha ido perfilándose en la jurisprudencia posterior, véanse las SSTC 18/1982, FJ. $14^{\circ}$ y $11 / 1986$, FJ. $5^{\circ}$.

31 STC 64/1990, FJ. 7.

32 Véase de nuevo AJa, E., El Estado autonómico. Federalismo y hechos diferenciales, op. cit., pág. 142 y Biglino Campos, P., "Lealtad constitucional en el Estado de las Autonomías", op. cit., pág. 69.

33 Véase SMEND, R., "Ungeschriebenes Verfassungsrecht im Monarchischen Bundesstaat”, en idem., Staatsrechtlichen Abhandlungen, op. cit., pág 56 y 57.

34 Véase Voigt, A., "Ungeschriebenes Verfassungsrecht”, Vereinigung der Deutschen Staatsrechtslehrer, núm. 10, 1952, pág. 33 y SCHÖCKER, S., "Ungeschriebenes Verfassungsrecht im Bundesstaat", Der Staat, núm. 5, 1966, pág. 326. Más recientemente en la doctrina, véase el tra- 
no) ${ }^{35}$ como se ha reflejado idénticamente a la doctrina y a la jurisprudencia comparada,${ }^{36}$ cuya función es reinterpretar aquellas disposiciones plasmadas en los textos constitucionales que regulan el reparto de las competencias entre los miembros del Estado descentralizado, con la finalidad de garantizar la eficacia de la unidad misma del sistema de distribución territorial de las funciones constitucionales. Esto cabe ser apreciado en cierta parte de la doctrina española, que ha concebido a la lealtad autonómica como una norma no escrita consustancial a la Constitución material. ${ }^{37}$

Esta concepción de la norma de lealtad constitucional como una exigencia teórico-funcional o, si se quiere, consustancial, al principio que descentraliza territorialmente la función de creación de normas es lo que permitiría calificar a la lealtad como una categoría atemporal. Y así, en el contexto del constitucionalismo alemán —donde la norma de lealtad ha obtenido su más relevante desarrollo práctico y doctrinal-, tanto en la Constitución del II Reich alemán de 1871 (incluso mucho antes, cuando ni siquiera puede hablarse propiamente de un Estado federal), como en la Constitución de Weimar de 1919, e incluso en la vigente Ley Fundamental de Bonn de 1949, ${ }^{38}$ edificadas sobre elementos estructurales tan dispares, la doctrina ha venido a reconocer implícitamente la existencia de una norma de lealtad. También esta manera de construir la lealtad se aprecia en la actualidad en otros ordenamientos estructuralmente federales europeos, como el austriaco, el belga, el italiano o el suizo, tal y como se ha reseñado al comienzo del trabajo. De acuerdo con estos parámetros pudiera resultar del todo comprensible el intento que ha hecho, en ocasiones, la doctrina española de importar de plano

bajo monográfico de Wolf, H. A., Ungeschriebenes Recht unter dem Grundgesetz, ed. Mohr, Tubinga, 2000.

35 No necesariamente coincidente con el concepto de metapositividad utilizado en el contexto de la doctrina material clásica de Constitución, si bien la construcción metapositiva de la lealtad federal ha llegado a ser sostenida en el contexto de sus propios presupuestos teórico-metodológicos, cfr. SMEND, R., "Ungeschriebenes Verfassungsrecht im Monarchischen Bundesstaat", op. cit., pág 56 y 57 y Sснмітт, C., Verfassungslehre, ed. Duncker \& Humblot, Berlín, 1989, pág. 364 y ss.

36 Véase en la doctrina Isensee, J., "Idee und Gestalt des Föderalismus im Grundgesetz", op. cit., pág. 532. En la jurisprudencia las BVerfGEE. 1, 299 (315), 4, 115 (129) y 36, 193 (202).

37 Cfr. AlberTí Rovira, E., "Las relaciones de colaboración entre el Estado y las Comunidades Autónomas", op. cit., pág. 136 y 137. También véase al respecto MuÑoz MachadO, S., Derecho Público de las Comunidades Autónomas, vol. I, ed. Cívitas, Madrid, 1984, pág. 185.

38 Véase primero, necesariamente, en la doctrina clásica sobre la Constitución, la teoría de Smend, a la que se le debe, en realidad, la primera elaboración dogmática del concepto de lealtad federal. Para el citado autor, la norma de lealtad federal se presentó como una exigencia teórica indispensable en el marco de la Constitución de 1871, al objeto de dotar de eficacia al pacto celebrado entre los Príncipes alemanes y que subyacía a aquél texto constitucional —cfr. SMEND, R., "Ungeschriebenes Verfassungsrecht im Monarchischen Bundestaat” op. cit., pág. 51—. Pero también en el contexto de la Constitución de Weimar de 1919, edificada sobre unos presupuestos diametralmente distintos; cfr. SMEND, R., "Verfassung und Verfassungsrecht" en IDEM., Staatsrechtlichen Abhandlungen, ed. Duncker \& Humblot, Berlín, 1968, pág. 272. La presente teoría ha sido importada por el mismo Tribunal Constitucional Federal alemán en el inicio de su actividad jurisprudencial, en su BVerfGE. 1, 299 (315) con alusión expresa a Rudolf Smend. 
al ámbito del principio autonómico de la CE de 1978 la construcción comparada de la lealtad federal. ${ }^{39}$

\section{LA SUPREMACÍA CONSTITUCIONAL COMO PRESUPUESTO PARA CONSTRUIR LA NORMA DE LEALTAD AUTONÓMICA}

Esta concepción de la lealtad al principio estructural que descentraliza territorialmente la función de creación de normas como una exigencia teóricofuncional — de la que se ha nutrido tanto la doctrina como la jurisprudencia españolas - ha sido objeto, no obstante, de ciertas críticas que han venido a poner en tela de juicio la tesis de la consustancialidad y, en definitiva, de la atemporaridad de la categoría de la lealtad, que en teoría habría de validar su potencial aplicabilidad a cualquier ordenamiento, entre ellos al español. ${ }^{40} \mathrm{Y}$ ello porque posiblemente el concepto de lealtad sea una consecuencia, primero, y externamente, de la asunción de un muy determinado concepto de Constitución y, después, internamente, de una concreta estructura del principio que descentraliza territorialmente las funciones de creación de normas. De otro modo resultaría difícil poder explicar por qué la construcción histórica de la lealtad -habiéndose considerado uniformemente como una exigencia consustancial a la distribución territorial de aquellas funciones- ha sido afirmada, sin embargo, en el seno de tales ordenamientos descentralizados con contenidos normativos bien diversos. Y así, la lealtad ha llegado a manifestarse como una norma de contenido bilateral y horizontal — dirigido a los miembros del Estado federal, reforzando el eficaz ejercicio de las competencias de cada uno de los Estados— ${ }^{41}$ como una norma unilateral y vertical,

39 Véase Muñoz Machado, S., Derecho Público de las Comunidades Autónomas, op. cit., pág. 185

40 Eso es lo que ha justificado las críticas manifestadas por la ciencia actual del Derecho Constitucional que han puesto en duda la posibilidad de importar de plano la construcción de la lealtad federal como una exigencia teórico-funcional al principio federal plasmado concretamente en la Ley Fundamental de Bonn de 1949, sin al menos llevar a cabo una reconstrucción dogmática de la lealtad al amparo de sus particulares presupuestos, que son del todo ajenos a una concepción pactista de la Constitución y al principio monárquico, pilares sobre los que se construyeron en su origen la doctrina de la lealtad federal. Sobre dichas críticas cfr. Hesse, K., Gründzüge des Verfassungsrechts der Bundesrepublik Deutschland, ed. CF. Müller, Heidelberg, 1990, pág. 109. Más recientemente véase el trabajo de Ковıотн, S., Integration und Bundestaat, ed. Duncker \& Humblot, Berlín, 1990, pág. 248 y ss.

41 En el Sacro Imperio Romano Germánico, en concreto, en la Paz de Augsburgo de 1555, se disponía la obligación de todos los Estados miembros — —Stände»— de adoptar un comportamiento recíproco de adecuada y buena lealtad. Por otro lado, en la Paz de Westfalia de 1648, en el art. VIII. 2 del Instrumentum Pacis Osnabrugensis se reconoció el derecho de los diferentes Estados —Reichsstände"— a celebrar tratados ("Bundnisrecht") entre sí y con Estados extranjeros, con la finalidad de garantizar su propia seguridad siempre que no atentasen contra los intereses del Kaiser ni del Reich. Esta concepción de la lealtad federal fue reiterada en el Acta Federal de 1815 y en la de Viena de 1820, si bien en este caso el derecho a celebrar acuerdos se reconocía para cualquier tipo de materia, véase sobre ello con carácter general BAuER, H., Die Bundestreue, op. cit., pág. 30 y ss. 
exigiendo el reforzamiento por parte de los Länder de la posición del Bund, ${ }^{42}$ o incluso, en la concepción mayoritariamente difundida en la actualidad, como una norma bilateral y vertical, dirigida a todos los miembros del Estado federal (al Bund y a los Länder) y destinada a dotar de eficacia, no a sus integrantes, sino a la unidad en la que aquellos se integran. ${ }^{43}$

Sólo la existencia de tal disparidad de modelos comparados de lealtad debiera hacer replantearse a la ciencia española del Derecho Constitucional la viabilidad de un automatismo en el momento de importar una categoría como la de la lealtad federal al ordenamiento español, y sobre todo, preguntarse si, como más bien parece, tras esos modelos de lealtad no se revelan, en puridad, elementos relativos a la estructura interna del ordenamiento jurídico. Sólo habiendo resuelto estas cuestiones podría otorgarse validez a la premisa que ha servido principalmente para importar la categoría de la lealtad federal al principio autonómico español: que en todo orden descentralizado ha de presuponerse, para poder garantizar su eficacia, una norma de lealtad.

Muy posiblemente los diferentes modelos históricos y doctrinales de lealtad que se han expuesto con anterioridad sean susceptibles de ser explicados de una manera coherente, tal y como se ha apuntado en cierta medida por un cierto sector doctrinal, a partir de la previa afirmación o no de una Constitución como norma jerárquicamente suprema ${ }^{44}$ En efecto, allí donde exista una Constitución como norma suprema, un elemento estructural asumido por la CE de 1978, seguramente cobre sentido el concebir a la lealtad como los dos últimos modelos históricos - como una norma que tiene por objeto dotar de eficacia al principio que descentraliza territorialmente la función creación de normas, más allá de las disposiciones competenciales en las

42 En el contexto de la Constitución alemana de 1871, véase Triepel, E., Unitarismus und Föderalismus im Deutschen Reiche, op. cit., pág. 29 y ss., modelo que se identifica con lo que ha dado en denominarse "Reichstreue".

43 Sobre ello véase IsENSEE, J., "Idee und Gestalt des Föderalismus im Grundgesetz", op. cit., pág. 643 y 644. En este modelo puede hablarse con propiedad de una "Bundestreue", no ya sólo de una "Reichstreue".

44 En realidad, la supremacía constitucional ha de considerarse como el presupuesto indispensable para poder hablar de lealtad constitucional, en general. La pretensión normativa de una Constitución consistente en dotar de eficacia a sus principios estructurales-lealtad constitucional - no puede derivar de otro aspecto que no sea su propia supremacía. La supremacía constitucional se manifiesta en las notas de fuerza activa y fuerza pasiva. El resultado que de ello se deriva (relevante a los efectos de la lealtad constitucional) es la indisponibilidad de las normas constitucionales frente a cualquier potestad de normación reconocida en el seno del ordenamiento. Esta indisponibilidad no despliega exclusivamente sus efectos en el plano de la validezdeclarando, como se ha afirmado, derogadas cualesquiera normas que contravengan lo dispuesto en la norma constitucional-, sino también en el de la eficacia. Y es que la voluntad de la Constitución de hacer indisponibles sus normas manifiesta, en realidad, su pretensión de que sean eficaces, esto es, de que se comprendan como una regulación estable del comportamiento humano, no sometida a la voluntad del legislador. Por ello, la supremacía de la Constitución tiene que aparecer como el fundamento de la norma constitucional de lealtad, esto es, como la justificación de su pretensión normativa consistente en dotar de eficacia a sus principios estructurales —en cuanto normas que concentran la eficacia de la Constitución-y, en último extremo, al ordenamiento jurídico en su conjunto. 
que aquél principio se materializa. ${ }^{45}$ En efecto, en el caso de una norma constitucional suprema y, por lo tanto, vinculante para los particulares y, en lo que aquí interesa, también para el poder público, adquiriría sentido obligar a los miembros del Estado descentralizado a ejercer sus competencias de un modo tal que se garantice la eficacia a la unidad del sistema (lealtad vertical). ${ }^{46} \mathrm{El}$ objeto de la pretensión de eficacia, ya no son los miembros del Estado descentralizado, sino la norma que articula la forma de Estado descentralizada. Por ello, la lealtad autonómica en la CE de 1978, si se admite la tesis de la consustancialidad de la lealtad al principio autonómico, parece que habría de concebirse de una manera coherente con el contenido que le ha imputado unánimemente tanto la doctrina como la jurisprudencia españolas (bilateral y vertical): el de una norma que exige del Estado y de las Comunidades Autónomas que, en ejercicio de sus competencias propias, garanticen la eficacia del principio autonómico, como una unidad normativa en la que sus respectivos sistemas jurídicos se integran. ${ }^{47}$

La existencia de una Constitución como norma suprema en la CE de 1978 permitiría otorgar, además, un adecuado encaje dogmático a la afirmación generalmente vertida acerca de que la lealtad constitucional desempeña la función de tutelar el interés general del Estado autonómico frente a los intereses particulares de sus integrantes, una afirmación ya clásica en la evolución de la categoría de la lealtad federal. ${ }^{48}$ De esta manera se ha expresado precisamente el Tribunal Constitucional, al afirmar que la obligación de lealtad constitucional exige que los integrantes del Estado autonómico se abstengan de adoptar decisiones o realizar actos que perjudiquen o perturben el interés general y tengan, por el contrario, en cuenta la comunidad de intereses que las vincula entre sí, que no puede ser menoscabada o disgregada a consecuencia de una gestión insolidaria de los propios intereses. ${ }^{49}$

45 Esto no pareció suceder en el modelo de la confederación, en el que el objeto de la lealtad no fue el principio estructural de una Constitución como norma suprema, que sencillamente no existía, sino las normas competenciales que las Constituciones de los Estados atribuían a éstos. Esto sea quizás lo que permita explicar que la lealtad se concibiera desde un punto de vista sólo horizontal, garantizando el ejercicio eficaz de las competencias de los diferentes Estados (soberanos de la confederación). Cfr. Kelsen, H., Allgemeine Staatslehre, op. cit., pág. 193 y ss, 207 y ss.

46 Esto es lo que pareció suceder ya en la construcción de la lealtad federal en el seno de la Constitución alemana de 1871 por parte de la teoría de la integración, a la que se le debe, recuérdese, la primera elaboración dogmática del significado de la categoría de la lealtad federal. Y así, con arreglo a una construcción de la supremacía constitucional a partir de criterios materiales, se concibió como Constitución al pacto celebrado entre los diferentes Príncipes alemanes. Pues bien, en base a esta supremacía, se exigió a los diferentes Príncipes que mantuviesen su lealtad al pacto, a la alianza que subyacía al texto constitucional de 1871. Véase en este sentido nuevamente el trabajo de SMEND, R., "Ungeschriebenes Verfassungsrecht im Monarchischen Bundestaat" op. cit., pág. 51.

47 Cfr. Albertí Rovira, E., "El interés general y las Comunidades Autónomas", Revista de Derecho Político, núm. 18-19, 1983, pág. 121; STC 18/1982, FJ. 14º.

48 BVerfGE. 43, 291 (348).

49 STC 64/1990, FJ. $7^{\circ}$. Esta misma concepción del interés general es la que se ha llegado a mantener en el caso del art. 155,1 CE, que faculta al Estado a adoptar determinadas medidas en 
Pero, en realidad, este presupuesto estructural del ordenamiento jurídico español: la existencia de una Constitución como norma suprema quizás se encuentre llamado, además, a desplegar nada despreciables consecuencias internamente, en la propia configuración normativa del principio autonómico plasmado en el art. 2. Con carácter general la doctrina y la jurisprudencia han ubicado el discurso de la lealtad autonómica en el contexto de una dualidad de miembros integrantes del principio autonómico: el Estado y las Comunidades Autónomas. En este mismo ámbito se ha ubicado la discusión sobre la construcción de la lealtad federal en el derecho comparado, que se ha circunscrito casi unánimemente al modelo bimembre del Estado federal: la federación y los Estados federados. ${ }^{50}$ Sin embargo, un detenido análisis de la cuestión, y aceptando el presupuesto de que para que pueda hablarse de lealtad debe existir una Constitución como norma suprema, quizás habría de conducir a plantearse si este concepto de Constitución no sería más coherente internamente, más que con una doctrina dual, con la doctrina que mantiene la existencia de tres miembros en el seno de un Estado territorialmente descentralizado. ${ }^{51} \mathrm{Al}$ fin y al cabo, la posibilidad de distinguir entre el interés general del Estado autonómico y los intereses particulares de los integrantes del principio del art. 2, sobre los que se construido el principio de lealtad autonómica, quizás cobre verdadero sentido si se distingue entre un ordenamiento soberano estatal — cuya norma cúspide sería la CE de 1978, con sus principios estructurales - reguladores de la función de creación normativa en los niveles superiores del ordenamiento- y los diferentes órdenes normativos parciales del Estado y de las Comunidades Autónomas.

\section{LA SUPREMACÍA JURÍDICO-NORMATIVA DE LA CE Y LA NEGACIÓN DE LA LEALTAD COMO NORMA CONSUSTANCIAL AL PRINCIPIO AUTONÓMICO}

La supremacía de la CE seguramente no sólo permita sentar las bases teóricas para una cierta estructura interna del principio autonómico que sea ca-

el caso de que las Comunidades Autónomas lesionen gravemente el interés general de España. Parte de la doctrina ha querido identificar en dicho enunciado la plasmación jurídico-normativa de una norma de lealtad destinada a dotar de eficacia al principio estructural del art. 2 CE. Sin embargo, posteriormente se tratará sobre ello. Véase por el momento AlberTí Rovira, E., "El interés general y las Comunidades Autónomas en la Constitución de 1978", op. cit., pág. 119 y 120. Véase también en un sentido parecido Cruz VILLALón, P., "La protección extraordinaria del Estado" en Pedrieri, A. y García de EnTerría, E. (edits.), La Constitución Española de 1978, ed. Cívitas, Madrid, 1984, pág. 717; así como López Guerra, L., Conflictos competenciales, interés general y decisión política, Revista del Centro de Estudios Constitucionales, núm. 1, 1988, pág. 91 y 92.

50 Véase con carácter general en la doctrina Maunz, T. y Zippelius, R., Deutsches Staatsrecht, ed. CH Beck, Múnich, 1991, pág. 103, y en la jurisprudencia, con expresa negación de la teoría de los tres miembros del Estado federal, véase la BVerfGE, 13, 54 (77).

51 Cfr. Kelsen, H., Allgemeine Staatslehre, op. cit., pág. 199 y 200 y Nawiasky, H., Allgemeine Staatslehre, ed. Verlagsanstalt \& Co. Ag. Einsiedeln, Zurich-Colonia, 1956, pág. 204. En la doctrina actual sobre la lealtad federal cfr. GEIGER, W., "Die Wechseltreuepflicht von Bund und Ländern" en Süsterhern, A., (edit.), Föderalistische Ordnung, ed. Rhenania, Koblenz, 1961, pág. 116 y ss. 
paz de justificar de una manera coherente el contenido normativo (vertical y bilateral) que tanto la doctrina como la jurisprudencia constitucional han querido atribuir a la lealtad autonómica. El particular modo con arreglo al que se construye muy particularmente la supremacía del documento constitucional de 1978 se encuentra llamada a enjuiciar críticamente el presupuesto mismo que ha servido para poder afirmar la existencia de tal norma: su supuesta consustancialidad al principio autonómico plasmado en el art. 2 CE. Como se ha expuesto con anterioridad, la tesis ampliamente difundida que ha intentado afirmar la existencia de una norma de lealtad al cualquier principio estructural que descentralice territorialmente la función de creación de normas ha partido de su concepción como una exigencia lógico-normativa indispensable que se deriva del reconocimiento de una pluralidad normativo-territorial en el seno de una misma unidad estatal. Y ciertamente, desde un plano lógico-jurídico quizás ello pueda ser una necesidad inmanente.

Sin embargo, lo que suscita mayores dudas es que la CE pueda ser compatible con el surgimiento de una exigencia de tal contenido. Y ello porque la supremacía de la CE no es el resultado de una jerarquía lógico-jurídica, lo que podría dar cauce al surgimiento de relaciones lógicas entre normas. La tesis que pretendió afirmar la consustancialidad de la lealtad al principio autonómico se halla ante el problema de que la supremacía de la CE no deriva de una jerarquía lógica - ni siquiera formal - aunque el texto constitucional haya asumido elementos propios de tales conceptos. ${ }^{52}$ La supremacía de la CE deriva de una jerarquía jurídico-positiva, de la expresa previsión como antijurídicas de cualesquiera normas que la contravengan. ${ }^{53}$ En lo que aquí interesa, ello implica que el ordenamiento jurídico español se muestra incompatible con las relaciones lógicas entre normas. Aun cuando estas puedan encontrarse justificadas en base a presupuestos lógicos, la CE no posibilita otras relaciones internormativas que aquellas que su normatividad jurídico-positiva ha querido reconocer. ${ }^{54}$ Uno de los elementos que en la CE pueden

52 El elemento material consistente en ocuparse de la regulación de la creación de normas por parte de los órganos superiores del Estado se lleva a cabo, por ejemplo, en los arts. 66, 82, 86 y 97 CE. Por su parte, el elemento formal cabe ser identificado en la unidad documental- el texto publicado en el BOE bajo el título Constitución Española de 1978-, y la rigidez de su reforma — mayoría de $3 / 5$ y $2 / 3$ prevista en los arts. 167 y 168 , de manera respectiva.

53 Sobre la negación de la asunción de estas teorías formalistas por parte de la Constitución Española y abogando por una concepción jurídico-positiva de su supremacía véase con carácter general Aláez Corral, B., Los límites materiales a la reforma en la Constitución Española de 1978, op.cit., pág. 262 y ss. Un detenido análisis de los conceptos de Constitución aquí expresados puede verse en FERNÁNDEZ-MirANDA CAMPOAMOR, A., "En torno al concepto de Constitución" en VVAA., La democracia constitucional. Estudios en homenaje a Francisco Rubio Llorente, ed. Congreso de los Diputados, Madrid, 2002, pág. 73 y ss.

54 No han faltado algunos intentos doctrinales de afirmar la invalidez de una reforma constitucional antidemocrática llevada a cabo a través del procedimiento democrático establecido en el Título X, sobre la base de su contrasentido lógico-jurídico, véase ejemplificativamente AraGón ReYes, M., Constitución y democracia, ed. Tecnos, Madrid, 1989, pág. 49. Con todo, como se ha venido a reconocer, ello sólo supondría un límite de carácter lógico que no halla acomodo en el concepto de Constitución asumido en el texto constitucional. Acerca de la inaplicabilidad de este 
constituir un mejor aval para poder afirmar su intención de concebirse como una norma plenamente positiva y articulada su supremacía sobre idénticos presupuestos jurídico-positivos: la posibilidad total de su reforma, se encuentra, sin embargo, llamada a desplegar nada despreciables consecuencias en lo que se refiere a una posible afirmación de una norma de lealtad autonómica en el ordenamiento español. En efecto, la viabilidad de que todo el contenido de la CE de 1978 pueda ser reformado, incluso el propio principio autonómico, lleva a la inevitable consecuencia de que, acaso fuera posible construir sobre la base de sus disposiciones una norma de lealtad, ésta no podría servir de base para poder postular la ilicitud de aquellas expectativas que abogasen por la instauración de un modelo territorial diametralmente distinto al previsto en el texto constitucional, ni siquiera el denominado derecho a la autodeterminación. ${ }^{55}$

En consecuencia, la tesis que mantiene la consustancialidad de la lealtad al principio autonómico no puede considerarse plenamente compatible con el concepto de Constitución asumido por la CE de 1978. La lealtad al principio del art. 2 sólo pudiera construirse a partir de las relaciones jurídico-normativas previstas explícita o implícitamente en ella entre las funciones normativas reconocidas constitucionalmente al Estado y a las Comunidades Autónomas, por un lado, y el principio autonómico, por otro, esto es, de la unidad normativa a partir de la que aquellas funciones se descentralizan.

Sin embargo, la negación de la teoría de la consustancialidad de la norma de lealtad al principio del art. 2 tiene, sin lugar a dudas, un efecto más relevante: la posibilidad de que la normatividad de la CE pudiera haber renunciado a plasmar una norma de lealtad al principio de descentralización territorial, llegando a consecuencias comparables a las que la doctrina ha imputado al modelo del federalismo dual, sustentado sobre una rígida separación competencial $^{56}$ que, tal y como se ha afirmado de manera un tanto cuestionable, se compadece mal con un deber consistente en coadyuvar al reforzamiento de la unidad estatal. De conformidad con las premisas ahora expuestas, resulta necesario analizar si la exigencia lógico-jurídica o, si se quiere, teórico-funcional, de la lealtad constitucional al principio autonómico ha adquirido una plasmación jurídico-normativa en las disposiciones de la CE de 1978.

tipo de límites lógicos a la reforma de la Constitución Española de 1978, véase AláEz Corral, B., Los límites materiales a la reforma de la Constitución de 1978, op. cit., pág. 312 y 313. Ese es el papel que desempeñan idénticamente otros límites, como la prohibición de que las normas del Título X puedan aplicarse a su propia reforma, o el que impide que mediante el procedimiento simple del art. 167 CE se puedan reformar las mayorías especialmente agravadas del art. 168.

55 Véase al respecto SolozÁbal Echavarría, J., Nación y Constitución. Soberanía y autonomía en la forma política española, ed. Biblioteca Nueva, Madrid, 2004, pág. 324 y ss., así como también Ruipérez Alamillo, J., Constitución y autodeterminación, ed. Tecnos, Madrid, 1995, pág. 117 y 118. También puede verse una interesante perspectiva en JÁUREGUI BERECIARTU, G., "El derecho de autodeterminación en la perspectiva del siglo XXI: especial referencia al País Vasco", ed. Revista de Occidente, núm. 241, 2001, pág. 231.

56 Cfr. Ducat, C. R. y Chess, H. W., Constitucional interpretation, ed. West Publishing, St. Paul y otros, 1988, pág. 35. 


\section{LA PLASMACIÓN JURÍDICO-NORMATIVA DE LA LEALTAD AUTONÓMICA. LA CONCEPCIÓN DOGMÁTICA DE LA LEALTAD AUTONÓMICA EN LA CE}

De cuanto se ha expuesto hasta aquí quizás puedan ser deducidas dos consecuencias fundamentales. La primera, que la norma de lealtad aparece inequívocamente como una exigencia dogmático-funcional allí donde se reconozca constitucionalmente un principio estructural cuyo objeto sea la distribución territorial de la función de creación de normas. Sin embargo, la segunda consecuencia, y quizás la fundamental, es que esta exigencia teórica en una Constitución que se conciba como una norma plenamente positiva, como la CE de 1978, no cabe ser convertida automáticamente en una norma jurídica. ${ }^{57}$ Lo que se impone es pues proceder a un examen del texto constitucional al objeto de determinar si aquélla exigencia lógico-jurídica, o para ser más exactos, teórico-funcional, puede encontrar acomodo en las disposiciones jurídico-positivas de la CE de 1978.

Ubicado el debate en estos términos, ha resultado usual querer identificar en el texto constitucional la concreción de dicho principio general no escrito de lealtad autonómica, concibiendo a la solidaridad y a los institutos de colaboración —en los que se ha encuadrado el auxilio, la coordinación y la cooperación - como la exteriorización formal de la lealtad autonómica. Sin embargo, en no pocas ocasiones, estos institutos han servido de base también para, de manera inversa, poder inferir a partir de ellos la existencia misma de una norma de lealtad autonómica. Cuando esto ha sucedido así, ese supuesto principio de lealtad autonómica ha sido caracterizado formalmente como principio de solidaridad o de colaboración, ${ }^{58}$ dándose lugar a una confusión

57 Algo que, sin embargo, ha parecido llevar a cabo la doctrina y la jurisprudencia constitucional, quizás al haber tratado de importar al ordenamiento español una categoría que encuentra su sustento teórico en un concepto de Constitución radicalmente distinto al que ha sido asumido por la CE. Posiblemente esta conversión sí tenga sentido en tales ordenamientos, pero no en el español. Véase sobre el proceder de la construcción de la lealtad federal al amparo particularmente del ordenamiento jurídico alemán las BVerfGEE.1, 14 (27) y 1, 299 (315). En la doctrina, véase Hesse, K., Grundzüge des Verfassungsrechts der Bundesrepublik Deutschland, op. cit., pág. 110, Stern, K., Das Staatsrechts der Bundesrepublik Deutschland, ed. CH Beck, Múnich, 1977, pág. 546 y BAYER, H. W., Die Bundestreue, op. cit., pág. 43.

58 Respecto a la solidaridad cfr. Muñoz Machado, S., Derecho Público de las Comunidades Autónomas, op. cit., pág. 184, 185 y 186. En lo que respecta a los institutos de colaboración, cfr. AJA, E., El Estado autonómico. Federalismo y hechos diferenciales, op. cit., pág. 143, SanTolaya MachetTi, P., Descentralización y cooperación, ed. Instituto de Estudios de Administración local, Madrid, 1984, pág. 33 y ss., Albertí Rovira, E., "Las relaciones de colaboración entre el Estado y las Comunidades Autónomas", op. cit., pág. 139 y Tajadura Tejada, J., El principio de cooperación en el Estado autonómico, ed. Comares, Granada, 2000, pág. 21. En la jurisprudencia véase la STC 204/2002 (FJ. $7^{\circ}$ ) que dispone: "si, como este Tribunal viene reiterando, el principio de colaboración entre el Estado y las Comunidades Autónomas está implícito en el sistema de autonomías (SSTC 18/1982, entre otras) y si ‘la consolidación y el correcto funcionamiento del Estado de las autonomías dependen en buena medida de la estricta sujeción de uno y otras a las fórmulas racionales de cooperación, consulta, participación, coordinación, concertación o acuerdo previstas en la Constitución y en los Es- 
conceptual necesitada de una adecuada delimitación. ${ }^{59}$ Quizás un detenido análisis de la CE de 1978 permita ofrecer una base suficiente para poder afirmar la existencia de diferentes normas de lealtad llamadas a desempeñar una función distinta respecto de la eficacia del principio estructural del art. 2 CE. Pero esta consecuencia en la CE, lejos de mostrarse como indefinida y fragmentada, seguramente pueda evidenciar una completa y coherente concepción dogmática global de la norma de lealtad al principio autonómico.

\section{EL PRINCIPIO TRANSVERSALIDAD COMO PLASMACIÓN NORMATIVA IMPLÍCITA DEL PRINCIPIO DE LEALTAD AUTONÓMICA}

Seguramente la plasmación normativa de la lealtad constitucional como genérica exigencia dogmático-funcional del principio autonómico pueda encontrarse implícitamente, por antonomasia, en el particular modo con que el principio del art. $2 \mathrm{CE}$ procede a distribuir territorialmente las funciones de creación de normas entre los integrantes del Estado autonómico. De este modo, tratando de ubicar el debate en sus justos términos, diríase que la lealtad constituye en la CE una norma inherente al principio autonómico del art. 2, no en cuanto principio de descentralización territorial de las funciones constitucionales en el marco de una unidad normativa soberana (legitimador de la lealtad como una exigencia teórica)— ${ }^{60}$ sino como un principio basado en un muy determinado modelo distributivo-competencial. En efecto, tal como se verá, según se practica el reparto competencial entre los integrantes del principio autonómico, el ejercicio de las competencias del Estado y de las Comunidades Autónomas sólo queda garantizado de un modo plenamente eficaz si aquellos sujetos adoptan, en el ejercicio de sus competencias propias, una conducta destinada a hacerlo posible. Por eso lo correcto sería entender a la lealtad autonómica implícita en el concreto modelo de Estado descentralizado consagrado en la CE. ${ }^{61}$

tatutos de Autonomía (STC 181/1988, FJ 7), este tipo de fórmulas son especialmente necesarias en estos supuestos de concurrencia de títulos competenciales en los que deben buscarse aquellas soluciones con las que se consiga optimizar el ejercicio de ambas competencias (SSTC 32/1983, 77/1984, 227/1987 y 36/1994), pudiendo elegirse, en cada caso, las técnicas que resulten más adecuadas: el mutuo intercambio de información, la emisión de informes previos en los ámbitos de la propia competencia, la creación de órganos de composición mixta, etc.".

59 Poniendo de manifiesto esta indeterminación conceptual véase JimÉnEz AsEnsio, R., Las competencias autonómicas de ejecución de la legislación del Estado, ed. Cívitas, Madrid, 1993, pág. 230 y 231; y también al respecto véase Cruz Villalón, P., "La doctrina constitucional sobre el principio de cooperación" en CANO Bueso, J., (coord.), Comunidades Autónomas e instrumentos de cooperación interterritorial, ed. Tecnos, 1990, pág. 119 y ss.

60 La que se refleja precisamente en la STC 12/1981, FJ $4^{\circ}$, convertida por el Tribunal Constitucional automáticamente en norma de lealtad.

61 En estos términos ha argumentado Fernández FarReres, G., "El principio de colaboración Estado-Comunidades Autónomas y su incidencia orgánica", Revista Vasca de Administración Púbica, núm. 6, 1983, pág. 205 y 206. 
La adecuada comprensión de esta exigencia jurídico-normativa sólo tiene lugar si se parte de la distinción teórica entre enunciado y norma. ${ }^{62}$ Sobre la base de este postulado, la lealtad autonómica ha de estimarse implícita en aquellos enunciados que practican un reparto competencial que sólo tiene sentido si se presupone implícitamente en ellos una norma destinada a hacerlo eficaz, garantizando en último lugar el desarrollo eficaz del principio estructural del art. 2 CE. ${ }^{63}$ Esta exigencia jurídico-normativa implícita que expresa la lealtad autonómica encuentra su justificación, muy particularmente, en el principio de transversalidad con arreglo al que se realiza el reparto competencial entre el Estado y las Comunidades Autónomas. Dicho principio aparece perfilado muy principalmente en los arts. 148 y $148 \mathrm{CE}$ y -a las resultas del principio dispositivo inherente al principio autonómico- en el bloque constitucional, integrado éste por un complejo normativo de rango formalmente infraconstitucional, pero ejerciente de una función materialmente constitucional: la completud de la estructuración de la creación normativa que, en sus rasgos más básicos, diseña el art. 2 CE. ${ }^{64}$

El principio de transversalidad es el responsable de que las funciones de creación y de aplicación de normas repartidas bajo la forma de competencias entre los sujetos del Estado autonómica se proyecten sobre un mismo ámbito de la realidad.$^{65}$ Este concreto aspecto es lo que conduce a que el ejercicio de una competencia, sin invadir propiamente ningún título competencial, pueda, sin embargo, producir una afectación o un condicionamiento de otras que concurren con aquélla misma en un idéntico sector de la realidad. ${ }^{66}$ Eso es lo que parece ponerse de manifiesto en el enunciado del art. $149,1,19^{\circ} \mathrm{CE}$, en el que se confiere al Estado la competencia sobre la pesca marítima, sin perjuicio de las competencias que, dentro de cada sector, se atribuyan a las Comunidades Autónomas. De esta incidencia de diferentes programas nor-

62 Cfr. Kelsen, H., Reine Rechtslehre, op. cit., pág. 73 y 74.

63 En esos términos ha llegado a pronunciarse, efectivamente, el Tribunal Constitucional, que ha afirmado que una u otra forma habrían estado de acuerdo con el deber de colaboración que, rectamente entendido, consiste en facilitar al máximo las competencias del otro ente. (STC 11/1986, FJ 14). Sin embargo, aquí puede verse lo anteriormente criticado, la indefinición terminológica que aqueja a la jurisprudencia constitucional, producto, quizás, de la confusión realizada de la lealtad con la colaboración.

64 Acerca de esta categoría y de su distinción con el bloque de la constitucionalidad —utilizado con anterioridad para aludir a aquélla primera categoría-, véase el trabajo de REQuEJo RoDRíGUEZ, P., Bloque constitucional y bloque de la constitucionalidad, ed. Servicio de Publicaciones de la Universidad de Oviedo, Oviedo, 1997, pág. 37 y ss., y 41 y ss.

65 Véase un análisis doctrinal sobre este modelo reconocido en la jurisprudencia TEROL BECERRA, M. J., De la jurisprudencia constitucional relativa a la estructura territorial del Estado. Análisis del cuatrienio 1995-1998, ed. Tirant lo Blanch, Valencia, 2001, pág. 80 y ss.

66 Como se puede ver, la lealtad sólo puede comprenderse adecuadamente si se parte de la distinción entre lo que es la invasión competencial y el menoscabo competencial, ámbito este último en el que pretende ejercer su función la norma de lealtad autonómica. Véase con carácter general en la doctrina PUNSET, R., "Los conflictos positivos de competencia", Revista Española de Derecho Constitucional, núm. 26, 1989, pág. 106 y 107. En la jurisprudencia véase asimismo la STC 203/1993, FJ. $3^{\circ}$. 
mativos sobre un mismo ámbito normativo hay que deducir, al menos, la obligación de desempeñar las competencias propias de manera que no resulten inadecuadamente afectadas o condicionadas las de otros miembros del Estado autonómico. ${ }^{67}$ Es en esta interrelación normativa en lo que ha de encontrar su explicación precisamente el contenido que la doctrina y la jurisprudencia constitucional han imputado unánimemente al instituto de la lealtad autonómica, aunque el particular modo de proceder a su construcción diste del que aquí se mantiene. ${ }^{68}$ Que esta norma efectivamente debiera haber resultado positivada - como se ha realizado sólo recientemente en el constitucionalismo italiano- ${ }^{69}$ y que debiera presidir ulteriores reformas del Estado autonómico es cierto, pero también lo es que su existencia implícita en la CE parece algo incontrovertible.

En virtud de lo hasta aquí expuesto, cabe afirmar que la función que ejerce la norma de la lealtad autonómica consiste en seleccionar interpretativamente - a través de mandatos y/o de prohibiciones, como se verá-, de entre todos los modos posibles de ejercer una competencia, el o los más adecuados para poder garantizar la eficacia normativa de las que corresponden a los demás integrantes del principio autonómico y que coinciden con aquélla en un mismo sector de la realidad. Como se puede ver, esta manera de fundamentar la existencia de la lealtad autonómica aparece como una exigencia normativa indispensable para que el modelo competencial que se articula en la CE de 1978 pueda ser posible. ${ }^{70}$ Pero además, es el hecho de que esta pretensión jurídico-normativa de eficacia implícita en el principio de transversalidad com-

67 Por aludir a otro ejemplo de confluencia competencial en un mismo sector de la realidad, puede aludirse aquí al art. 149, 1, 22 $\mathrm{CE}$, que atribuye al Estado la legislación, ordenación y concesión de recursos y aprovechamientos hidráulicos cuando las aguas discurran por más de una Comunidad Autónoma, y la autorización de instalaciones eléctricas cuando su aprovechamiento afecte a otra Comunidad o el transporte de energía salga de su ámbito territorial, en relación con el art. $148,10^{\circ} \mathrm{CE}$, que reconoce a las Comunidades Autónomas la competencias sobre proyectos, construcción y explotación de los aprovechamientos hidráulicos, canales y regadíos de interés de la Comunidad Autónoma; las aguas minerales y termales.

68 Véase con carácter general Muñoz Machado, S., Derecho Público de las Comunidades Autónomas, op, cit., pág. 186 y también García DE ENTERría, E., La ejecución autonómica de la legislación del Estado, ed. Cívitas, Madrid, 1983, pág. 140. En la jurisprudencia véase la STC 152/1988, FJ. 6․

69 Tal como ha sucedido particularmente con la reforma realizada en el año 2001 del enunciado del art. 120 de de la Constitución italiana en el que se ha consagrado un "principio di leale collaborazione"; véase al respecto en la doctrina CAvAlieri, P., Diritto regionale, ed. Cedam, Padua, 2003, pág. 294 y ss. Este principio se había afirmado ya implícitamente en diferentes resoluciones de la Corte Costituzionale, véanse sólo a título de ejemplo las Sentencias 359/1985, 204/1993 y 341/1996.

70 Esto ha parecido ponerse de manifiesto por MuÑoz MACHado, S., Las potestades legislativas de las Comunidades Autónomas, ed. Cívitas, Madrid, 1979, pág. 98. Esta pretensión normativa de eficacia ha tenido la ocasión de ponerse de relieve por el Tribunal Constitucional en la STC 11/1986, en la que se estableció que la competencia estatal para la ratificación de las denominaciones de origen, requisito indispensable para que sus consecuencias se extiendan más allá de la Comunidad Autónoma, debe ejercerse por parte del Estado de manera diligente, expresa y motivada al objeto de no diferir la eficacia de las competencias de las Comunidades Autónomas. 
petencial surja no sólo unidireccionalmente, del Estado respecto de las Comunidades Autónomas, sino también de éstas respecto de aquél — de lo que constituye un expresivo ejemplo la transversalidad de las competencias económicas (arts. 131,1 1 y 133,2 CE) — lo que explica que el contenido de la norma de lealtad adquiera, de conformidad con la configuración del principio de transversalidad, una estructura bilateral, en lo que ha puesto su énfasis unánimemente la doctrina y la jurisprudencia constitucional. ${ }^{71}$

Pero el principio de transversalidad también ofrece un suficiente amparo normativo a los contenidos que tradicionalmente se han imputado a la norma de lealtad autonómica, si bien ellos, como se ha puesto de manifiesto con anterioridad, han sido mayoritariamente importados de construcciones comparadas. Del principio de transversalidad cabe deducir cómo la función interpretativa de la norma de lealtad autonómica, de contenido bilateral, se hace valer tanto con arreglo a mandatos que requieren una conducta activa, o si se quiere, favorable al eficaz ejercicio competencial, como a través de prohibiciones que prescriben un comportamiento pasivo. En efecto, en determinados casos, según se configura el principio de transversalidad, la tutela de la eficacia de las competencias que concurren en un mismo ámbito normativo requerirá la adopción de un determinado acto normativo. Eso es lo que sucede, por ejemplo, en el caso del art. art. 149,1, $29^{\circ} \mathrm{CE}$, que reconoce a las Comunidades Autónomas la competencia en materia de seguridad pública en el marco de lo dispuesto en una ley orgánica estatal. En este caso, en el supuesto de que éstas hayan asumido estatutariamente la competencia sobre la creación de policías, el ejercicio de la potestad de normación del Estado aparece como un acto debido, dándose así cobertura a un contenido activo de la norma de lealtad autonómica. ${ }^{72}$ Sin embargo, con carácter general, constituyen un mayor número de supuestos en los que la lealtad parece re-

71 Véase en la doctrina AJA, E., El Estado autonómico. Federalismo y hechos diferenciales, op. cit., pág. 142 y AlberTí Rovira, E., "El interés general y las Comunidades Autónomas", op. cit., pág. 120 y 121. En la jurisprudencia, véase a título de ejemplo la STC 18/1982, FJ. 14º.

72 Pero, en realidad, bien mirado, la incidencia de diferentes programas normativos en un mismo ámbito normativo, si bien constituye el presupuesto para que pueda derivarse la lealtad autonómica, cuya función normativa consiste en reinterpretar el modo en que deben de desempeñarse las competencias, no ha de conducir en todo caso derivar tal exigencia implícita, so pena de alterar indebidamente el contenido del principio autonómico, sobre el cual ejerce una función nada despreciable el resto de principios estructurales del art. 1,1. Y muy principalmente el principio democrático del que el art. 2 constituye su plasmación. Cfr. PORTERo MolinA, J. M., "Principio democrático y principio de autonomía", op. cit., pág. 185. También sobre la interdependencia de los principios estructurales de la CE, véase Garrorena Morales, A., El Estado español como Estado social y democrático de derecho, ed. Tecnos, Madrid, 1984, pág. 204 y ss. Precisamente porque el principio democrático faculta al legislador incluso a no normar bajo determinadas circunstancias, en base a la lealtad autonómica no podría distorsionarse el complejo entramado de los principios estructurales haciendo debida una normación que en modo alguno puede considerarse exigible. Esto parece resultar válido fundamentalmente en los casos en los que el Estado aparece como competente para la aprobación de legislación básica, en cuyo contexto pueden proceder al desarrollo las Comunidades Autónomas. Exigir del Estado en todos los casos un deber de normación parece contravenir el propio contenido del principio democrático. 
sultar más compatible con un contenido pasivo, requiriéndose de los sujetos del Estado autonómico, por así decir, una prohibición de menoscabo de las competencias concurrentes en un mismo ámbito normativo. De ello dejan constancia los supuestos anteriormente esgrimidos al principio de este epígrafe para aludir a la configuración del principio de transversalidad en la CE de 1978.

Hasta aquí se ha tenido la oportunidad de dejar constancia de la existencia de una norma de lealtad autonómica implícita en el principio de transversalidad, que desempeña su función interpretativamente y, además con un contenido activo y pasivo. Sin embargo, otra de las cuestiones que ha de ser objeto de análisis es si dicha norma de lealtad ha de entenderse dotada, además, de un contenido universal. Esta universalidad es la que parece encontrarse en el trasfondo de las posiciones mantenidas en el contexto del ordenamiento español que han tratado de afirmar la existencia de un "principio" de lealtad autonómica, llamado a interpretar el conjunto de las relaciones entre el Estado y las Comunidades Autónomas. ${ }^{73}$ Una conclusión tal, argumentada de conformidad con las premisas que aquí se exponen, requeriría un análisis en detalle de todos los títulos competenciales existentes, a fin de examinar cuáles de los programas normativos recogidos en los arts. 148 y $149 \mathrm{CE}$ resultan coincidentes en un mismo ámbito normativo, algo que excede con creces del objeto de este trabajo. ${ }^{74}$

Sin embargo, sólo por la horizontalidad del reparto competencial realizado en la CE de 1978 y en el bloque constitucional hace prácticamente muy difícil hallar algún supuesto en el que no quepa hablar de una exigencia normativa de eficacia, esto es, de una norma de lealtad autonómica. Más aún, como se ha llegado a reconocer, incluso en el hipotético supuesto de un reparto puramente vertical - más compatible con un modelo de federalismo dual- es posible encontrar incluso ciertos elementos de transversalidad. ${ }^{75} \mathrm{Y}$ ello parece apreciarse adecuadamente en la CE. En efecto, también en las denominadas competencias exclusivas, como las que se reconocen en el art. 149

73 En lo que se refiere a la doctrina, véase con carácter general AJA, E, Tornos, J.,FOnT, T., Perulles, J. M., Albertí, E., El sistema jurídico de las Comunidades Autónomas, op. cit., pág. 85, Muñoz Machado, S., Derecho Público de las Comunidades Autónomas, op. cit., pág. 184, 185 y 186 y García Roca, J., "Asimetrías autonómicas y principio constitucional de solidaridad”, Revista Vasca de Administración Pública, núm. 47 (II), 1997, pág. 73. En la jurisprudencia, véase ejemplificativamente la STC 152/1988, FJ. 6o.

74 Evidentemente este proceder no resulta necesario cuando la construcción de la lealtad autonómica es el resultado de la conversión de una exigencia teórica de eficacia en una exigencia jurídico-normativa, algo que ha sido una constante en la doctrina y la jurisprudencia constitucional.

75 Cfr. Ducat, C. R. y Chess, H. W., Constitucional interpretation, op. cit., pág. 357. Esta teoría de la verticalidad en el reparto de las funciones constitucionales es en la que se ha basado la denominada teoría de la impermeabilidad, aplicada históricamente a la interpretación del principio de división de poderes, concibiendo a éste como un principio de rígida distribución vertical, cfr. JeluineK, G., System der subjetiven öffentliche Rechte, ed. Scientia, Aalen, 1979, pág. 195 y 196 y LaBand, P., Das Staatsrecht des Deutschen Reiches, op. cit., 1911-1914, pág. 181. 
CE, resulta viable apreciar ciertos elementos de transversalidad compatibles con el surgimiento de una pretensión implícita de eficacia, esto es, con una norma de lealtad autonómica. Piénsese, por ejemplo, en la competencia exclusiva estatal del art. $149,1,2^{\circ}$, relativa a la inmigración, de gran trascendencia actual. Pues bien, si bien en su programa normativo — contrariamente a lo que sí sucede en otros, ya expuestos- no aparece consagrada de una manera expresa ninguna relación de transversalidad - reflejando la coincidencia de títulos competenciales en un mismo ámbito normativo- tal cosa puede deducirse de una lectura conjunta con las competencias del art. 148 $\mathrm{CE}$, que pueden ser asumidas por las Comunidades Autónomas. Y así, quizás no fuera demasiado complejo llegar a colegir que el ejercicio de la competencia exclusiva estatal puede llegar a afectar o a condicionar la competencia autonómica de asistencia social (art. 148, 1, 20 ), entre otras. ${ }^{76}$ En consecuencia, a partir de la configuración normativa de la transversalidad en la CE, pero también en el bloque constitucional, hay buenas razones para poder afirmar que de aquélla cabe deducir un principio (general) de lealtad autonómica en el ordenamiento español.

Pero la transversalidad configurada en la CE y en el bloque constitucional muy posiblemente no avale tan sólo su idoneidad para poder erigirse en un parámetro general de constitucionalidad de las conductas del Estado y de las Comunidades Autónomas - a lo que se ha parecido aludir en la doctrina y en la jurisprudencia, al invocar su naturaleza como principio-.${ }^{77}$ Seguramente la

76 Y así, por ejemplo, si el Estado llevase a cabo una política excesivamente permisiva en lo que se refiere a la concesión de permisos de residencia en el seno del Estado español, esto podría poner en peligro la eficacia de la competencia autonómica de asistencia social que se lleva a cabo también sobre los inmigrantes. Por eso precisamente será necesario presuponer de manera implícita una norma de lealtad autonómica destinada a permitir el ejercicio eficaz de las competencias autonómicas. Esta norma exigiría directamente, y en un primer momento, una limitación por parte del Estado en lo que se refiere a la admisión de inmigrantes. Sin embargo, el Estado podría llevar a cabo su política si otorgase recursos financieros suficientes destinados a permitir el ejercicio eficaz de la competencia autonómica de asistencia social.

77 Ello requiere, al menos, que se expongan los mecanismos procesales destinados a controlar el cumplimiento de la norma de lealtad autonómica. Y así, en primer lugar, el control de la norma de lealtad podría enjuiciarse en el marco del recurso y la cuestión de inconstitucionalidad, a través del que podrían ser impugnadas las normas (con rango de ley) dictadas tanto por el Estado como por las Comunidades Autónomas que, en ejercicio de competencias propias, lesionen la eficacia de las competencias respectivas del otro ente, pues ello estaría proscrito por el principio de lealtad autonómica implícito en el reparto transversal de las competencias. El presupuesto indispensable para poder aplicar en este ámbito la norma de lealtad autonómica es que se ejerza una competencia propia, ya que de otro modo no se estaría ante un menoscabo competencial —en lo que pone su énfasis la norma de lealtad autonómica-, sino ante una usurpación competencial. Los conflictos de competencias que se suscitan entre el Estado y las Comunidades Autónomas, así como entre éstas, son también adecuados para poder enjuiciar jurisdiccionalmente el cumplimiento de las normas de lealtad autonómica presentes en la Constitución y en el bloque constitucional. En lo relativo a los conflictos positivos, pueden conducir a declarar inconstitucionales actos normativos que no posean necesariamente ni fuerza ni valor de ley. En ese sentido, los conflictos positivos de competencia completan la posibilidad de control de constitucionalidad de los actos normativos que potencialmente pueden infringir la norma de 
norma de la transversalidad, contenido nuclear el principio autonómico del art. 2 CE avale el sentido quizás más técnico del concepto "principio" en su contraposición a la noción de regla. ${ }^{78}$ En efecto, tal y como se configura la transversalidad en el reparto territorial de la función de creación de normas, posiblemente lo correcto sea afirmar que lo que aparece como mandado o prohibido por medio de la norma de lealtad que se deriva de aquélla es una conducta que ha de ser cumplida de la mejor manera posible, en el marco de las condiciones normativas y fácticas existentes. Dicho en otros términos, que la actividad prescrita por la lealtad autonómica consiste en garantizar de la mejor manera posible el ejercicio eficaz de las competencias que concurren con ella en un mismo ámbito normativo y, en último extremo, la eficacia del principio autonómico. Por ello, la decisión judicial potencialmente resolutiva de su cumplimiento habrá de versar - también por la indispensable interpretación de la norma de lealtad autonómica conforme a las exigencias dogmáticas del principio estructural de Estado democrático de derecho- sobre si la competencia ejercida se encuadra, al menos, en alguna de las posibles maneras de garantizar la eficacia del principio autonómico.

\section{LA SOLIDARIDAD Y LOS INSTITUTOS DE COLABORACIÓN COMO NORMAS DE LEALTAD Y SU CONCEPCIÓN FUNCIONAL AL SERVICIO DE LA EFICACIA DEL PRINCIPIO DE LEALTAD AUTONÓMICA}

Como se acaba de poner de manifiesto, la lealtad autonómica puede ser concebida como una exigencia jurídico-normativa implícita del principio autonómico plasmado en el art. 2 CE, muy concretamente del principio de transversalidad que predetermina su reparto competencial. Sin embargo, como se ha puesto de relieve con anterioridad, en ocasiones el principio de lealtad autonómica ha querido verse reflejado en las normas de solidaridad y en los institutos de colaboración. No obstante, quizás, la concepción de la solidaridad y de los institutos de colaboración como la exteriorización formal de la norma implícita de lealtad autonómica no refleje más que una confusión entre el contenido de todas aquellas categorías, ${ }^{79}$ cuando bien mirado las dos primeras normas ejercen una función respecto del principio del art. 2

lealtad autonómica. En el caso de los conflictos negativos de competencia, a través de esta vía podrían resultar impugnables el resto de comportamientos pasivos que no son alegables mediante el recurso y la cuestión de inconstitucionalidad. Unos comportamientos pasivos que son numéricamente los más propicios para poder constituir una infracción de la norma de lealtad.

78 Sobre la distinción entre regla y principio véase Alexy, R., Theorie der Grundrechte, ed. Nomos, Baden-Baden, 1985, pág. 87 y ss.

79 Poniendo de manifiesto esta indeterminación conceptual véase JIMÉNEZ AsENSIO, R., Las competencias autonómicas de ejecución de la legislación del Estado, op. cit., pág. 230 y 231; y también al respecto véase Cruz Villalón, P., "La doctrina constitucional sobre el principio de cooperación" en Cano Bueso, J., (coord.), Comunidades Autónomas e instrumentos de cooperación interterritorial, ed. Tecnos, Madrid, 1990, pág. 119 y ss. 
CE bien distinta a la que despliega lealtad implícita en el principio de transversalidad.

En lo que se refiere a la solidaridad, es cierto que su genérica proclamación en el art. 2 CE podría dar cauce para poder construir un principio de carácter general llamado a presidir la interpretación de las relaciones existentes entre el Estado y las Comunidades Autónomas; ${ }^{80}$ máxime cuando la norma de solidaridad aparece reconocida en un contexto enunciativo en el que se reconoce la autonomía dentro de una unidad. En ese sentido, no sería desacertado pensar, en efecto, que la solidaridad no sería más que la exteriorización de la exigencia teórico-funcional que surge allí donde se reconoce no sólo territorialmente una dispersión de fuentes de producción en el seno de una misma unidad normativa. Y en realidad ha sido precisamente dicha disposición la que ha servido de manera mayoritaria para concebir a la solidaridad como la expresión del principio de lealtad autonómica. ${ }^{81}$ Sin embargo, un detenido análisis del documento constitucional seguramente deba avalar una posición contraria, en la medida en que tanto los arts. 158,1 y $2 \mathrm{CE}$, entre otros enunciados, parecen haber querido circunscribir la pretensión normativa de eficacia de la solidaridad del art. 2 CE a un ámbito exclusivamente económico, como así lo ha interpretado, por otra parte, el legislador del bloque constitucional. ${ }^{82}$ De cualquier forma, una argumentación tal, muy posiblemente pueda constituir una apoyatura en exceso endeble al hallarse apegada, es cierto, a la literalidad de la CE; sobre todo para quienes pretendan interpretar al art. 158 CE sólo como una de las múltiples esferas a las que proyecta su eficacia la norma de la solidaridad. ${ }^{83}$

Sin embargo, la literalidad constitucional se halla, en este caso, sustentada también en argumentos de dogmática constitucional, muy particularmente,

80 Véase Montoro Chiner, M. J., Convenios entre federación y Estados miembros en la República Federal alemana. Solidaridad y lealtad constitucional en los sistemas alemán y español, ed. Tecnos, Madrid, 1987, pág. 21.

81 Véase ejemplificativamente Muñoz Machado, S., Derecho Público de las Comunidades Autónomas, op, cit., pág. 186, García de EnTERría, E., La ejecución autonómica de la legislación del Estado, op. cit., pág. 140, Jiménez Blanco, A., Las relaciones de funcionamiento entre el poder central y los entes territoriales, Instituto de Estudios de la Administración Local, Madrid, 1985, pág. 247, así como Alonso de ANTONIO, J. A., "El principio de solidaridad en el Estado autonómico. Sus manifestaciones jurídicas", op. cit., pág. 54 y ss. Véase en la jurisprudencia la STC 152/1988, FJ. 6.

82 Cfr. Albertí Rovira, E., "El interés general y las Comunidades Autónomas", op. cit., pág. 121. Esta conclusión favorable a la identificación de la solidaridad con una dimensión económica ha resultado avalada por el legislador del bloque constitucional, que en el art. 2 b) de la Ley Orgánica de Financiación de las Comunidades Autónomas ha dispuesto que "La garantía del equilibrio económico, a través de la política económica general, de acuerdo con lo establecido en los artículos 40.1, 131 y $138 \mathrm{CE}$, corresponde al Estado, que es el encargado de adoptar las medidas oportunas tendentes a conseguir la estabilidad económica interna y externa y la estabilidad presupuestaria, así como el desarrollo armónico entre las diversas partes del territorio español".

83 Sobre la extensión de la solidaridad a otros ámbitos, relacionados con diferentes contenidos de los principios de Estado social y democrático de derecho, véase ejemplificativamente Alonso de Antonio, J. A., "El principio de sollidaridad en el Estado autonómico. Sus manifestaciones jurídicas", op. cit., pág. 54 y 55. 
en términos de lealtad constitucional. Si, tal y como se ha reconocido unánimemente, la lealtad autonómica se concibe en la CE de 1978 como una norma que, dirigida idénticamente al Estado y a las Comunidades Autónomas —asumiendo una estructura bilateral—, tiene por objeto garantizar el funcionamiento eficaz del principio autonómico, parece claro que el mismo contenido que asume la solidaridad dirigida al Estado habría que fundamentarlo coherentemente en cuanto norma que tiene como destinatarias a las Comunidades Autónomas. Sin embargo, en este aspecto, las posiciones que han querido afirmar un contenido universal para la solidaridad lo han hecho fundamentalmente al nivel del Estado - como destinatario principal de tal norma (art. 138,1 CE)—_ ${ }^{84}$, reconociendo el ámbito económico de la solidaridad dirigida a las Comunidades Autónomas, como por otra parte se reconoce expresamente en el art. 156 CE. Esta ausencia de equilibrio en el contenido de las normas de solidaridad que se dirigen al Estado y a las Comunidades Autónomas se conjuga mal con la posibilidad de construir, a partir de la solidaridad, un principio general de lealtad autonómica.

El problema de la circunscripción de la pretensión de eficacia de la solidaridad a un ámbito, aunque relevante, bien concreto, lo comparten los institutos de colaboración. En efecto, tanto el auxilio, la coordinación y la cooperación circunscriben su función en la CE y en el bloque constitucional a ámbitos bien concretos, mucho más delimitados que el propio de la solidaridad. El auxilio, delimitado a la posibilidad de celebración de convenios entre Comunidades Autónomas (art. 145,1 CE), ${ }^{85}$ la coordinación como una facultad dirigida al Estado para establecer un procedimiento coordinador sólo en el ámbito de la planificación general de la economía, la investigación científicotécnica y sanidad (arts. 149, 1, 13, $15^{\circ}$ y $16^{\circ}$ ), ${ }^{86}$ y la cooperación prevista en el bloque constitucional en supuestos bien concretos, como las conferencias sectoriales, las comisiones mixtas de transferencias o las Juntas de Seguridad, ${ }^{87} \mathrm{di}^{-}$ fícilmente pueden ser adecuados para poder deducir un principio general de

84 Poniendo de manifiesto la dimensión principalmente unilateral de la solidaridad véase AlberTí Rovira, E., "El interés general y las Comunidades Autónomas", op. cit., pág. 120.

85 Véase Fernández Farreres, G., "El principio de colaboración Estado-Comunidades Autónomas y su incidencia orgánica", op. cit., pág. 205. Un análisis acerca de la pretensión de eficacia de los convenios véase en Albertí Rovira, E., "Los convenios entre Comunidades Autónomas", Documentación Administrativa, núm. 240, 1994, pág. 112; también JiMÉNEZ BlANCO, A., "Convenios de colaboración entre el Estado y las Comunidades Autónomas", Documentación Administrativa, núm. 240, 1994, pág. 94 y ss. En lo que se refiere al significado de los convenios en el derecho comparado puede consultarse García Morales, M. J., Los convenios de colaboración en los sistemas federales europeos. Estudio comparativo de Alemania, Suiza, Austria y Bélgica, ed. Mc- Graw-Hill, Madrid, 1998. Por su parte, en la jurisprudencia, véase con carácter general la STC 74/1983, FJ 50.

86 No sucede en España lo que en la Constitución italiana, que consagra con carácter general un "principio di lealle collaborazione" (art. 119), conforme al cual se ha estimado viable doctrinalmente poder extender el ámbito material de la coordinación, circunscrita por el art. 120 a muy determinados ámbitos materiales, véase 1 respecto Bartole, S., Bin, R., Falcon, G. y Tosi, R., Diritto regionale, op. cit., pág. 203 y ss.

87 Sobre ello véase Albertí Rovira, E., "Las relaciones de colaboración Estado-Comunidades Autónomas", op. cit., pág. 161. 
lealtad autonómica llamado a interpretar el conjunto de las relaciones entre el Estado y las Comunidades Autónomas.

Sin embargo, quizás un poderoso argumento en orden a mantener la distinción entre las normas de solidaridad y de colaboración por un lado, y la norma de lealtad autonómica que se encuentra implícita en el principio de transversalidad, por otro, sea el diferente modo con arreglo al que las mismas desempeñan su función consistente en dotar de eficacia al principio estructural plasmado en el art. $2 \mathrm{CE}$. Tal como se ha visto, la función de esta última norma de lealtad constitucional se hace valer interpretativamente, modulando el contenido normativo de una relación jurídica de transversalidad en el ejercicio de las funciones constitucionales. De tal modo, en el ámbito de dicha norma de lealtad resulta necesario distinguir la norma que crea una interrelación entre las funciones y la norma misma de lealtad llamada a operar sobre aquélla. Siendo esto así, el principio de lealtad, en sentido estricto, no ejercería su función creando mandatos, permisos o prohibiciones, sino que reinterpreta los ya impuestos por la norma de que diseña la transversalidad. Por ello, cabe afirmar que la norma implícita de lealtad autonómica asume lo que se ha dado en llamar en el contexto de la doctrina comparada un contenido restrictivo. ${ }^{88}$ Sin embargo, eso no parece suceder en el caso de la solidaridad y en los institutos de colaboración, a través de cuyo contenido se imponen, mandatos y prohibiciones que crean una nueva relación jurídica entre órganos distintos.

Esto es lo que se pone de relieve, por antonomasia, en la solidaridad, que impone al Estado mandatos de contenido económico que crean una nueva relación jurídica entre aquellos sujetos, no derivada de la relación de transversalidad que se despliega en el plano de las competencias económicas. $^{89}$ De tal relación de transversalidad lo único que cabría deducir es el deber de ejercer las competencias de manera tal que se permita de manera respectiva su desempeño eficaz. ${ }^{90}$ No obstante, el deber impuesto al Estado, por ejemplo, consistente en dotar a las Comunidades Autónomas de recursos

88 Véase Bautr, H., Die Bundestreue, op. cit., pág. 175 y ss.

89 Esta transversalidad en materia económica es la que se produce como resultado del enunciado del art. 131,1 CE, en el que se reconoce al Estado la competencia sobre la planificación general de la economía, y del enunciado del art. 156,1 del texto constitucional que atribuye a las Comunidades Autónomas autonomía financiera; transversalidad que se da también en materia tributaria en los enunciados de los arts. 133,1 (Estado) y 133,2 (Comunidades Autónomas).

90 Lo que exigiría la norma de lealtad autonómica implícita en el principio de transversalidad diseñado por las normas constitucionales aludidas en la nota anterior es que el Estado, por ejemplo, al ejercer su planificación general sobre la economía, permita a las Comunidades Autónomas desempeñar eficazmente sus competencias económicas. Y así, si el Estado planificara la actividad económica general de una manera extraordinariamente restrictiva, por ejemplo, pretendiendo conseguir un superávit, podría llegar a impedir el ejercicio eficaz de las competencias que el art. 156,1 CE reconoce a las Comunidades Autónomas ya que éstas tienen el deber de respetar el equilibrio fijado por el Estado. Por tanto, el Estado cumple con el principio de lealtad autonómica simplemente planificando la actividad económica general de forma que las Comunidades Autónomas puedan llevar a cabo su propio sistema impositivo y presupuestario. 
económicos suficientes (art. 158,2 CE) crea una relación adicional entre el Estado y las Comunidades Autónomas no contenida en la obligación que deduce de la transversalidad. Por ello, cabe afirmar que la solidaridad presenta un contenido extensivo y no restrictivo. A la misma conclusión parece tener que llegarse en el supuesto de los institutos de colaboración, donde el auxilio faculta al auxilio autonómico, y la coordinación y la cooperación mandan al Estado y a las Comunidades Autónomas someterse a procedimientos coordinadores y/o cooperativos. ${ }^{91}$ Esto aparece como un argumento de extraordinaria relevancia para, de un lado, justificar por qué la norma de lealtad propia del principio de transversalidad puede deducirse de forma implícita de la Constitución, lo que no ocurre con los de solidaridad y colaboración, y de otro, por qué estas últimas normas despliegan una pretensión de eficacia distinta a la de la primera norma.

Cosa enteramente distinta es que la norma de la solidaridad y los institutos de colaboración posean una determinada relación con la norma de lealtad que se encuentra implícita en el principio de transversalidad, revelando, así, la asunción por parte de la CE de una concepción dogmática acabada y bien definida de la lealtad al principio autonómico. En realidad, la solidaridad y los institutos de colaboración cobran auténtico sentido cuando existe previamente una relación transversalidad (en la que se fundamentan dogmáticamente y sobre la que están llamados a operar). Esto se puede apreciar con una especial intensidad en el caso de los institutos de colaboración del principio autonómico, que presuponen lógicamente que sus sujetos desempeñen funciones materialmente afines —esto es, que se proyecten sobre un mismo ámbito de la realidad-, lo que justifica la obligación de colaborar (bien a través de la coordinación o de la cooperación). ${ }^{22}$ Pero también, el de-

91 Precisamente porque la función de la solidaridad y de colaboración es crear una relación competencial, su existencia no podría afirmarse sin una expresa plasmación en el documento constitucional. Así lo ha puesto de manifiesto AlberTí Rovira, con ocasión del tratamiento de la coordinación en el ámbito autonómico. Según el citado autor, aun cuando, con carácter general, el principio de colaboración aparece como exigencia (dogmática) derivada del carácter territorialmente descentralizado del Estado español, la coordinación no puede afirmarse más que en aquellos casos en los que la Constitución la haya establecido expresamente. Fuera de dichos ámbitos, la coordinación sólo aparece como algo voluntario, cfr. Albertí Rovira, E., "Las relaciones de colaboración entre el Estado y las Comunidades Autónomas", op. cit., pág. 147. Sin embargo, no han faltado posiciones que han pretendido deducir la existencia un principio general de coordinación del art. 103.1 CE, que establece entre los principios de actuación de la administración pública la eficacia y la coordinación, cfr. SANTOlaya MachetTi, P., Descentralización y cooperación, op. cit., pág. 108. Esta posibilidad debe de considerarse dudosa, ya que tal disposición, por su ubicación sistemática y por su expresión textual, parece referirse más bien a la Administración del Estado en sentido estricto, como integrante del Gobierno de la Nación, quedando excluidos de ella el Parlamento de la Nación y los órganos legislativos y ejecutivos de las Comunidades Autónomas.

92 Esta exigencia dogmática ha sido puesto de manifiesto precisamente por el Tribunal Constitucional. Debe traerse aquí nuevamente a colación la dicción de la STC 204/2002 (FJ. $7^{\circ}$ ): "Si, como este Tribunal viene reiterando, el principio de colaboración entre el Estado y las Comunidades Autónomas está implícito en el sistema de autonomías (SSTC 18/1982, entre otras) y si 
ber de solidaridad cobra sentido, aunque no solamente, para satisfacer aquellos presupuestos necesarios para poder proceder a cumplir las obligaciones que se deriven para las Comunidades Autónomas del cumplimiento del principio de lealtad autonómica derivado de la intersección material de sus competencias con otras del Estado. ${ }^{93}$ En puridad, en virtud de lo expuesto hasta aquí, cabe afirmar que la función de las normas de lealtad contenidas en la solidaridad y en la colaboración desempeñan la función de reforzar las posibilidades de ejercicio eficaz de las competenciales distribuidas transversalmente y, en último lugar, de la eficacia de la norma de lealtad llamada a operar sobre dicha relación. Por ello, las normas de lealtad contenidas en la solidaridad y en los institutos de colaboración ejercen una función preventiva - frente a la represiva propia de la lealtad implícita en la transversalidad-.${ }^{94}$

`la consolidación y el correcto funcionamiento del Estado de las autonomías dependen en buena medida de la estricta sujeción de uno y otras a las fórmulas racionales de cooperación, consulta, participación, coordinación, concertación o acuerdo previstas en la Constitución y en los Estatutos de Autonomía (STC 181/1988, FJ 7), este tipo de fórmulas son especialmente necesarias en estos supuestos de concurrencia de títulos competenciales en los que deben buscarse aquellas soluciones con las que se consiga optimizar el ejercicio de ambas competencias (SSTC 32/1983, 77/1984, 227/1987 y 36/1994), pudiendo elegirse, en cada caso, las técnicas que resulten más adecuadas: el mutuo intercambio de información, la emisión de informes previos en los ámbitos de la propia competencia, la creación de órganos de composición mixta, etcétera".

93 Piénsese, por ejemplo, en la Ley Orgánica 5/2000, de responsabilidad penal de los menores. En este caso, la ley, en el art. 54, prevé la posibilidad de que las medidas privativas de libertad, la detención y las medidas cautelares de internamiento acordadas frente a los menores de edad se ejecuten en centros especiales de internamiento. En ese sentido, y en base a la norma de lealtad autonómica que se encuentra implícita en la distribución transversal de las competencias, las Comunidades Autónomas tienen el deber de adoptar las medidas normativas y organizativas para permitir que la competencia del Estado - la regulación orgánica de la responsabilidad penal del menor - pueda ser eficaz. Sin embargo, como se puede ver, el cumplimiento de esta norma de lealtad puede hacer que el ejercicio de las competencias - ejecutivas - de las Comunidades Autónomas puedan ser ineficaces ya que puede irrogarles un gasto económico excesivo que impida no sólo el eficaz ejercicio de sus competencias sino también el eficaz cumplimiento de la norma de lealtad respecto del Estado. Pues bien, la norma de solidaridad tiene un efecto instrumental en este caso, al querer garantizarles la capacidad económica suficiente para que ello pueda ser posible a través del Fondo de Suficiencia previsto en la Ley Orgánica 8/1980, de Financiación de las Comunidades Autónomas, revisable anualmente.

94 Sin embargo, para que esta función pudiera llegar a ejercerse en todos sus extremos sí hubiera sido recomendable hacer coincidente el ámbito sobre el que actúa la pretensión de eficacia de la solidaridad y de los institutos de colaboración con el propio de la transversalidad, a cuya eficacia aquellos sirven, si bien ello, como se ha visto, no ha sido así. Para explicar esto quizás puede aludirse al enunciado del art. 149, 1, $19^{\circ} \mathrm{CE}$ en el que se confiere al Estado la competencia exclusiva sobre la pesca marítima, sin perjuicio de las competencias que, dentro de cada sector se atribuyan a las Comunidades Autónomas. En este caso, tendría sentido establecer un procedimiento coordinador para poder ensamblar eficazmente todas aquellas competencias que inciden sobre el mismo sector de la realidad. Sin embargo, aunque dogmáticamente resulta exigible una norma de coordinación, no ha obtenido cobertura desde un punto de vista normativo, ya que la coordinación no aparece como una competencia estatal en dicha materia. 


\section{LA FACULTAD DE COERCIÓN AUTONÓMICA COMO NORMA DE LEALTAD DE CIERRE} DEL SISTEMA

Aunque el debate sobre la posible existencia de una norma de lealtad autonómica en el ordenamiento español haya girado fundamentalmente entorno a la norma de solidaridad y a los institutos de colaboración, en relación con la eventual existencia de un principio implícito de lealtad autonómica, cuya interrelación funcional ha pretendido ser examinado anteriormente con arreglo a una concepción constitucionalmente adecuada del principio autonómico, muy posiblemente la concepción dogmática de la lealtad autonómica en la CE no se encuentre sólo predeterminada por aquellas normas. Seguramente en ella, como ha llegado a ser apuntado por algún sector doctrinal, desempeñe alguna función la norma que subyace al enunciado del art. 155,1 CE, que faculta al Estado a adoptar ciertas medidas contra las Comunidades Autónomas en el caso de que atenten gravemente contra el interés general de España. Posiblemente uno de los modos más coherentes de otorgar un sentido normativo a esta cláusula sea entenderla alusiva al interés general de la unidad normativa soberana que instaura el principio estructural del Estado autonómico, más allá, por lo tanto, de los intereses de cada uno de los miembros que conforman el mismo, que seguramente deba identificarse con la tutela de la eficacia de sus órdenes normativos parciales. Si se admite que ese sea el objeto de la norma del art. 155,1 CE - lo que encuentra también un aval en los arts. 144,1 y 150,3 CE_, ${ }^{95}$ parece que lo más coherente sea concebirla también como una norma de lealtad autonómica.

95 Y así, por ejemplo, el 144, 1 CE faculta al Estado a suplir la ausencia de determinados requisitos contemplados en el art. 143, 1 para la constitución de las Comunidades Autónomas cuando lo exija el interés nacional. Aceptando la elemental identificación entre la cláusula de interés nacional y la dispuesta en el art. 155, 1 (interés general de España), el ejercicio por parte del Estado de las facultades del art. 144.1 CE se reconoce cuando sean necesarias para la eficacia del principio autonómico. Esta eficacia precisamente fue la que motivó la inclusión de la provincia de Segovia, que inicialmente no se había unido a ninguna otra para la constitución de una Comunidad Autónoma, en la Comunidad de Castilla-León. La eficacia del principio autonómico también justificó la suplencia de la fase iniciativa en la provincia de Almería en la que no se dieron las mayorías requeridas por el art. 151.1 CE para su constitución, junto a otras provincias, en Comunidad Autónoma, aunque se persiguiera vulnerando el mandato de sujeción, ya que la posibilidad de suplir la fase de iniciativa se reconoce en el art. 144.1 de la Constitución para las provincias que intenten constituirse en Comunidad Autónoma por el procedimiento simple del art. 143.1. Esta misma función es la que parece desempeñar el art. 150, 3, al reconocer al Estado la posibilidad de aprobar leyes que establezcan los principios necesarios para armonizar las disposiciones de las Comunidades Autónomas, aun en el caso de materias atribuidas a la competencia de éstas cuando así lo exija el interés general. La facultad estatal para dictar leyes de armonización se reconoce, tal y como ha afirmado la jurisprudencia constitucional, en el caso de que se aprecie que el sistema de distribución de competencias es insuficiente para evitar que la diversidad de disposiciones normativas de las Comunidades autónomas produzca una desarmonización contraria al interés general de la nación. STC 76/1983, FJ. $3^{\circ}$. 
Esta conclusión, que ha sido implícitamente avalada por parte de la doctrina, ${ }^{96}$ exigiría, sin embargo, una mayor profundización en orden a determinar cuál es la relación existente entre esta norma de lealtad y las ya estudiadas, fundamentalmente con aquella implícita en el principio de transversalidad, pero también con las que tratan de garantizar preventivamente su eficacia (la solidaridad y los institutos de colaboración). Quizás un somero análisis del enunciado del art. 155,1 CE permita hacer ver que la función que ejerce la norma de lealtad autonómica contenida en el mismo es bien distinta a la que ejercen aquellas otras normas de lealtad. Esto parece ser la consecuencia de lo que bien podría tildarse como principio de excepcionalidad, que rige el supuesto de hecho de la aplicabilidad de las consecuencias jurídicas de la norma de lealtad del art. 155,1. ${ }^{97}$ En ese sentido, podría afirmarse que mientras la disposición de lealtad autonómica del art. 155,1 CE resulta de aplicación en supuestos extraordinarios, el principio de lealtad autonómica implícito en el principio de transversalidad y las que garantizan preventivamente la eficacia normativa de aquél — la solidaridad y los institutos de colaboración - resultan aplicables a las relaciones de funcionamiento ordinario entre los sujetos del Estado autonómico.

En virtud de lo expuesto, la norma de lealtad autonómica consagrada en el art. 155,1 CE aparece como la norma de lealtad de cierre de la eficacia del sistema autonómico, y la que culmina la concepción dogmática de la norma de lealtad autonómica asumida por el texto constitucional de 1978. Al igual que la solidaridad y los institutos de colaboración desempeñaban la función de garantizar preventivamente la eficacia de la norma matriz de lealtad implícita en el principio de transversalidad, la lealtad del art. 155,1 CE tiene como función garantizar, en último extremo, y en casos excepcionales, la eficacia normativa de todas aquellas otras normas de lealtad autonómica. Por ello muy posiblemente haya que entender que el supuesto de hecho de la aplicación de la norma de lealtad autonómica del art. 155,1 CE se encuentre conformado por la infracción de las normas de lealtad aplicables a las relaciones de funcionamiento ordinario entre los sujetos del Estado autonómico.98

96 Cfr. Albertí Rovira, E., "El interés general y las Comunidades Autónomas” „op. cit., pág. 119 y 120, así como Cruz Villalón, P., "La protección extraordinaria del Estado”, op. cit., pág. 717.

97 Esto ha resultado pacífico en la doctrina, véase al respecto AJA, E, Tornos, J.,FonT, T., PERulles, J. M., Albertí, E., El sistema jurídico de las Comunidades Autónomas, op. cit., pág. 471 y Muñoz Machado, S., Derecho Público de las Comunidades Autónomas, op. cit., pág. 455-457. En la jurisprudencia véase la STC 49/1988, (FJ. 31º). Por ello no puede entenderse que la norma de lealtad constitucional que se encuentra implícita en el reparto transversal de las competencias, aplicable al funcionamiento ordinario del Estado autonómico español constituye la plasmación de la norma de lealtad constitucional contenida en el enunciado del art. 155,1 CE.

98 Por ello, quizás la solución que parezca constitucionalmente más adecuada en orden a interpretar el contenido de las medidas de coerción estatal, en la medida en que permite argumentar en términos de lealtad, parece ser la que faculta al Estado a incumplir algunas de las normas que tienen como función dotar de eficacia a las competencias de las Comunidades Autónomas. En concreto, el art. 155, 1 se concebiría como una cláusula de exclusión de la ilicitud de la inobservancia de las normas de lealtad dirigidas al Estado. Esto pudiera resultar más coherente 
ABSTRACT.-The concept of "Constitutional Loyalty" has been hardly analyzed by the Spanish Scholarship or Courts. Its treatment has been limited to the sphere of the Autonomous State. Nevertheless, the lack of a express rule of loyalty in the Spanish Constitution has tried to be replaced by the improper category of "federal loyalty", which has been used by other systems of law. This paper purposes to prove how an implicit rule of "autonomous loyalty" can be deduced from the precepts of the Spanish Constitution. Likewise, this work has tried to specify the content that this rule has in the Constitution, due to its imprecise definition by the Scholarship and the Spanish Constitutional Court.

que aquellas otras posiciones que se han difundido en la doctrina española y que han llegado a afirmar que entre las medidas que puede adoptar el Estado en ejercicio de la función del art. 155,1 se encuentra la ejecución subsidiaria de las competencias de las Comunidades Autónomas - lo que se han denominado medidas de sustitución-, la negación de los efectos jurídicos a las normas procedentes de aquéllas o incluso la disolución de los órganos autonómicos. Véase al respecto Aja, E, Tornos, J.,Font, T., Perulles, J. M., Albertí, E., El sistema jurídico de las Comunidades Autónomas, op. cit., pág. 473 y García de Enterría, E., La ejecución autonómica de la legislación del Estado, op. cit., pág. 184. 